Portland State University

PDXScholar

Environmental Science and Management

Faculty Publications and Presentations

$4-1-2016$

\title{
The Biological Sediment Tolerance Index: Assessing Fine Sediments Conditions in Oregon Streams using Macroinvertebrates
}

\author{
Shannon Hubler \\ Oregon Department of Environmental Quality \\ David Huff \\ NOAA Fisheries \\ Patrick M. Edwards \\ Portland State University, patrick.edwards@pdx.edu \\ Yangdong Pan \\ Portland State University, pany@pdx.edu
}

Follow this and additional works at: https://pdxscholar.library.pdx.edu/esm_fac

Part of the Environmental Sciences Commons

Let us know how access to this document benefits you.

\section{Citation Details}

Hubler, S., Huff, D. D., Edwards, P., \& Pan, Y. (2016). The Biological Sediment Tolerance Index: Assessing fine sediments conditions in Oregon streams using macroinvertebrates. Ecological Indicators, 67, 132-145. http://doi.org/10.1016/j.ecolind.2016.02.009

This Article is brought to you for free and open access. It has been accepted for inclusion in Environmental Science and Management Faculty Publications and Presentations by an authorized administrator of PDXScholar. Please contact us if we can make this document more accessible: pdxscholar@pdx.edu. 


\title{
The Biological Sediment Tolerance Index: Assessing fine sediments conditions in Oregon streams using macroinvertebrates
}

\author{
Shannon Hubler ${ }^{\mathrm{a}, *}$, David D. Huff ${ }^{\mathrm{b}}$, Patrick Edwards ${ }^{\mathrm{c}}$, Yangdong Pan ${ }^{\mathrm{c}}$ \\ a Oregon Department of Environmental Quality, 3150 NW 229th Ave., Hillsboro, OR 97124, USA \\ ${ }^{\mathrm{b}}$ Estuarine and Ocean Ecology, Northwest Fisheries Science Center, NOAA, Point Adams Research Station, PO Box 155, Hammond, OR 97121, USA \\ ' School of the Environment, Department of Environmental Science and Management, Portland State University, PO Box 751, Portland, OR 97207, USA
}

\section{A R T I C L E I N F O}

\section{Article history:}

Received 17 November 2015

Received in revised form 26 January 2016

Accepted 2 February 2016

Available online 25 April 2016

\section{Keywords:}

Fine sediments

Macroinvertebrates

Tolerances

Weighted averaging

\begin{abstract}
A B S T R A C T
Fine sediments in excess of natural background conditions are one of most globally common causes of stream degradation, with well documented impacts on aquatic communities. The lack of agreement on methods for monitoring fine sediments makes it difficult to share data, limiting assessments of stream conditions across jurisdictions. We present a model that circumvents these limitations by inferring fine sediments in Oregon streams through sampling of macroinvertebrates. Tolerances to fine sediments $(<0.06 \mathrm{~mm}$ diameter) were calculated for 240 macroinvertebrate taxa, from a calibration dataset of 446 sites across Oregon, as well as an independent validation dataset of 50 samples. Weighted averaging methods were used to infer fine sediment levels in streams by weighting the tolerances of modeled taxa observed in a sample by their abundances. The final model, the Biological Sediment Tolerance Index (BSTI), showed a strong relationship to measured fine sediments (calibration $r^{2}=0.49$, validation $r^{2}=0.58$ ). Rootmean-squared-error was small in the calibration dataset ( $2 \%$ fines), but larger in the validation dataset (14\% fines). Repeatability was assessed by examining variability in BSTI at 14 sites across Oregon. Because field methods for sampling macroinvertebrates are standardized across resource agencies in Oregon and the responses of macroinvertebrates represent the actual effects of fine sediments on stream ecosystems, the BSTI may offer water resource managers' a cost-effective method for assessing fine sediment conditions in their ongoing efforts to improve water quality across the state.
\end{abstract}

(C) 2016 Elsevier Ltd. All rights reserved.

\section{Introduction}

Excess fine sediments are a leading cause of stream impairments across the world, frequently associated with biological impairments of stream ecosystems (Chutter, 1969; Ryan, 1991; Fossati et al., 2001; Paulsen et al., 2008). Effects from excess sedimentation are known to result in impairments to all levels of stream communities (Wood and Armitage, 1997; Suttle et al., 2004; Jensen et al., 2009; Jones et al., 2012). In the Pacific Northwest (PNW) region of the United States, these impairments have been directly related to declines in culturally and economically important salmon populations. For example, altered sediment regimes were identified as a high stress factor in 31 out of 40 Southern Oregon/Northern

* Corresponding author at: 3150 NW 229th Avenue, Hillsboro, OR 97124, USA. Tel.: +1 5036935728.

E-mail addresses: hubler.shannon@deq.state.or.us (S. Hubler), david.huff@noaa.gov (D.D. Huff), patrick.edwards@pdx.edu (P. Edwards), pany@pdx.edu (Y.Pan).
California coho salmon populations (NMFS, 2014), with impacts most frequently greater on the earliest life stages (Suttle et al., 2004; Jensen et al., 2009). While it is generally accepted that excess fine sediments may alter ecosystem function, based on both field (Von Bertrab et al., 2013) and experimental studies (Mathers et al., 2014; Jones et al., 2015), agreement on how to measure fine sediments and what levels are protective of aquatic life remains elusive.

Many resource management agencies in Oregon have broadscale monitoring programs in place to measure and quantify stream substrate composition, however, the ability to easily utilize that information across programs is limited due to differences in field protocols (Roper et al., 2010). Additionally, Oregon's water quality standards for sedimentation provide no guidance on monitoring sediment conditions, nor at what levels may produce impairments: "The formation of appreciable bottom or sludge deposits or the formation of any organic or inorganic deposits deleterious to fish or other aquatic life or injurious to public health, recreation, or industry may not be allowed (Oregon Administrative Rule 340-041-0007-11)." This lack of clarity from resource management agencies, in addition to 
complicated field methods, causes confusion in the public-making it difficult to engage citizen-based groups in monitoring sediment conditions. In periods of reduced monitoring budgets, the ability to combine data across resource management agencies or to boost sampling efforts through volunteer monitoring organizations would greatly improve our understanding of the impacts of fine sediments on Oregon's streams.

Biomonitoring of benthic macroinvertebrates offers a potential solution to these problems through stressor-response modeling of macroinvertebrates to fine sediments. Macroinvertebrates are the most widely used indicators of stream biological conditions (Rosenburg and Resh, 1993; Hering et al., 2004) and are commonly used to assess stream conditions at regional (Hawkins et al., 2000; Hargett et al., 2007), state (Ode et al., 2008) and national scales (Wright et al., 1993; Smith et al., 1999; Paulsen et al., 2008). Due to their high taxonomic diversity, central position in stream ecosystem food-webs, and varied feeding strategies and habitat requirements, macroinvertebrates are effective indicators of biological conditions. Furthermore, the relatively longer life-cycles (from several months to several years) of macroinvertebrates integrate stream conditions through time (Hawkes, 1979; Cairns and Pratt, 1993; Hodkinson and Jackson, 2005).

Macroinvertebrate monitoring offers several advantages to monitoring fine sediments alone. First, macroinvertebrate field sampling methods have been standardized among the major PNW monitoring programs since the early 2000s (Hayslip, 2007), allowing for ease of transfer of comparable data among programs. Second, macroinvertebrate taxonomists in the PNW routinely work collaboratively to increase similarity in taxonomic information across laboratories (PNAMP, 2015). Another advantage provided by macroinvertebrate monitoring is public engagement. Macroinvertebrate field collection methods are relatively simple and easy to train to novices, and as long as taxonomic identification is standardized can show a high degree of similarity between professional and non-professional samples (Fore et al., 2001; Engel and Voshell, 2002). Finally, macroinvertebrate sampling offers a more costeffective way of assessing stream ecological conditions than by monitoring for a single stressor. While monitoring for instream fine sediments alone may indicate a potentially impaired system, it is particularly useful to understand whether or not excess fine sediments are resulting in actual impairments to the community of organisms that we are trying to protect. Macroinvertebrate diagnostic indices have been developed for temperature (Yuan, 2007), stream acidity (Hamalainen and Huttunen, 1996; Larsen et al., 1996), and fine sediments (Extence et al., 2013; Relyea et al., 2012). Thus, the true cost-effective nature of biomonitoring can be realized when we integrate a suite of diagnostic indexes capable of identifying multiple potential causes of biological impairments, while requiring a single sample (e.g., Chessman and McEvoy, 1998). This last step requires thorough knowledge of individual taxonomic responses to a given stressor, such as we present here with fine sediments.

Macroinvertebrates may be strongly influenced by excess fine sediments (McClelland and Brusven, 1980; Lemly, 1982; Wood and Armitage, 1997). Responses to fine sediments are often taxon-specific, with effects observed on survival (Strand and Merritt, 1997), burial (Wood et al., 2005), egg hatching success (Kefford et al., 2010), growth (Kent and Stelzer, 2008), feeding (Hornig and Brusven, 1986), and relative abundance and richness (Angradi, 1999; Kaller and Hartman, 2004). Analyzing taxonspecific responses, or tolerances, to fine sediments allows for the creation of a diagnostic index to identify for a specific cause of impairment.

In the field of bioassessment, the term tolerance is often used to reflect taxon-specific responses to environmental gradients potentially altered by human activities (Yuan, 2004). There has been a recent movement to develop more rigorous and quantitative tolerance designations for individual taxa at various spatial scales. Carlisle et al. (2007) examined macroinvertebrate genera and families throughout the United States (US), developing tolerances to ions, nutrients, temperature, and both suspended and bedded fine sediments. Yuan (2004) determined tolerances to $\mathrm{pH}$, nutrients, sulfate, and stream habitat within the Mid-Atlantic region of the US. Tolerances for land-cover (e.g., \% forested) were developed for macroinvertebrates in the PNW (Black et al., 2004). Relyea et al. (2012) quantified macroinvertebrate taxa responses to fine sediments, then developed an index based on classification of those tolerances into discrete classes. Taken further, tolerances (i.e., optima) across taxa can be adapted into an assemblage-level index to infer stressor levels.

There are various approaches used in modeling tolerances to environmental gradients from biological samples. The need for transparent and quantifiable methods in setting management goals has moved the science away from the long-time standard of expert opinion. A frequently used approach is to rank tolerances into discrete classes. For example Extence et al. (2013) used a traits-based approach to model linkages between fine sediments and morphological or physiological adaptations in macroinvertebrates. Relyea et al. ranked macroinvertebrate tolerances based on abundance percentiles across a fine sediment gradient. Multivariate ordination, followed by ranked tolerances was used by Murphy et al. (2015) for fine sediments and Carlisle et al. (2007) for multiple stressors. But for developing continuous tolerances, which arguably is a more objective approach, weighted averaging (WA) (ter Braak and Barendregt, 1986) is perhaps the most commonly used technique.

WA has been frequently used to make inferences of historical environmental gradients for diatoms in lentic systems (Ter Braak and van Dam, 1989; Birks et al., 1990; Hall and Smol, 1992). More recently, WA has been used to infer environmental gradients in streams for diatoms (Pan et al., 1996; Ponader et al., 2007) and macroinvertebrates (Hamalainen and Huttunen, 1996; Larsen et al., 1996; Yuan, 2007). Performance and bias in WA models are susceptible to the range and evenness of sampling along the environmental gradient (ter Braak and Looman, 1986; Yuan, 2005) and to covarying factors (Yuan, 2007). WA may be considered less rigorous than other methods of inferring environmental gradients, such as maximum likelihood (ML) (Ter Braak and van Dam, 1989; Yuan, 2007), WA partial-least-squares regression (WA-PLS) (Ter Braak and van Dam, 1989; Larsen et al., 1996; Birks, 1998), or Boosted Regression Trees (Juggins et al., 2015). However, WA frequently performs as well as other methods and offers a suitable alternative to more complex methods (Ter Braak and van Dam, 1989; Birks et al., 1990; Birks, 1998; Juggins et al., 2015).

Our primary objective was to develop a biological index for inferring fine sediment conditions in streams across Oregon. We expanded on prior studies by modeling macroinvertebrate tolerances to smaller substrate particle sizes $(<0.06 \mathrm{~mm})$ than were previously examined ( $<2 \mathrm{~mm}$; Yuan, 2007; Relyea et al., 2012). First, we quantitatively defined taxon-specific responses of macroinvertebrates to fine sediments. Second, we used these taxa responses to infer fine sediment levels, based exclusively on a macroinvertebrate sample. Our goal is to generate an index, the Biological Sediment Tolerance Index (BSTI) which may be used as a cost-effective method for assessing fine sediment conditions in Oregon streams. We intend for the index to be used by a broad range of resource managers, such as government agencies with well-developed biological monitoring programs to citizen-based monitoring organizations with relatively minimal resources and experience. 


\section{Methods}

\subsection{Study sites}

We sampled 496 unique sites across Oregon for which we had paired macroinvertebrate assemblage and substrate composition data (Fig. 1). Most sites were selected randomly as part of spatially balanced surveys intended to make unbiased estimates of stream conditions across various spatial scales (Herlihy et al., 2000; Olsen and Peck, 2008), although a smaller proportion of sites were hand-selected based on various study designs. All sites were sampled during summer low-flow conditions (June-September), from 1999 to 2004 . Study reaches ranged from 150 to $800 \mathrm{~m}$ in length, and consisted entirely of wadeable streams and rivers that allowed surveyors to safely wade across the width and along the thalweg. We used a calibration dataset of 446 sites (CAL) to build our models, randomly setting aside 50 sites as an independent validation dataset (VAL).

\subsection{Macroinvertebrate data}

Macroinvertebrate assemblages were sampled from riffle habitat with a D-frame kicknet. Eight individual $0.09 \mathrm{~m}^{2}$ kicks were distributed randomly across the reach and composited into a single sample (Peck et al., 2006). Samples were preserved in the field with 95\% ethanol. Macroinvertebrates were randomly sorted in the laboratory for a subsample target of 500 individuals (Caton, 1991). The sorted macroinvertebrates were identified to lowest-practical taxonomic level. Identifications were standardized to ensure consistent treatment across all samples, so that no ambiguous taxa were present in a sample (Cuffney et al., 2007). This procedure resulted in 240 operational taxonomic units (OTUs), of which $82 \%$ were at the genus to species level, $15 \%$ were at family to tribe, and $3 \%$ were at higher taxonomic levels.

\subsection{Environmental data}

To measure fine sediments throughout Oregon, stream substrates were surveyed over a reach length of 40-times the average wetted width, using protocols consistent with Kaufmann et al. (1999) and Peck et al. (2006). At each of 21 evenly spaced transects, five substrates were selected at distances of $0 \%, 25 \%, 50 \%$, $75 \%$, and $100 \%$ of the wetted width. A total of 105 particles per reach were visually assessed into one of 11 size classes, based on its median diameter. While visual estimates of substrate size are known to result in higher error and bias than measured values, the use of this approach provides a practical yet ecologically meaningful measure of sediment conditions (Faustini and Kaufmann, 2007; Glendell et al., 2014). To identify individual particles, the sampler's index finger was slid down a stadia rod to identify the particle size at each substrate sampling location. Fine sediments were the smallest of the 11 size classes and defined as silt or clay particles with a median diameter less than $0.06 \mathrm{~mm}$. At this size, it was not possible to identify individual fines particles, but rather flocs of fines were distinguished from sand as not gritty when rolled between the fingers, similar to Glendell et al. (2014). Fine sediments were further defined as actual deposits and accumulations, not simply thin layers of fine sediment deposits over larger substrates (e.g., cobbles and boulders).

We calculated additional environmental and habitat characteristics to examine the similarities between the CAL and VAL datasets. Mean width and percent canopy cover were calculated from the same habitat surveys as fine sediments (Stoddard et al., 2005; Peck et al., 2006). We used Geographic Information Systems (GIS) to calculate elevation at the bottom of the sampling reach, stream gradient (slope), catchment area, and two climate-related variables (precipitation and air temperature; PRISM, 2004). A Human Disturbance Index was calculated from three GIS coverages at the catchment-scale (forest fragmentation, road density, and percent urban and agricultural landuse) and a reach-scale assessment of all human activities (Drake, 2004).

\subsection{Taxa tolerances and inference models for fine sediments}

In this paper, we use the generalized term tolerance (Yuan, 2004) to describe a taxon's response to human caused increases in fine sediments. We distinguish the use of tolerance in a manner similar to that of the term optima in an ecological sense, used to define a taxon's maximum along an environmental gradient, and not in the WA modeling sense of tolerance as the width of the taxon response-curve. Accordingly, a taxon's tolerance for percent fine sediments (\%FN) is the point along the fine sediment gradient where abundances are maximized. Then, if we have an understanding of each taxon's response to increasing fine sediments, we can use the tolerances of all taxa found in a sample to make inferences of the fine sediment conditions within a stream reach (ter Braak and Looman, 1986).

We selected WA as the "minimal adequate model" (e.g., Birks, 1998) for inferring fine sediments from the biota. We explored multiple modeling alternatives to WA (ML, WA-PLS, WA tolerance down-weighting), but found simple WA to provide models with equivalent or better performance (data not shown). We used WA in C2 software (Juggins, 2007) to compute macroinvertebrate fine sediment tolerances and inference models of \%FN. According to Birks (1998), the best WA models are typically those that include all taxa, even those with few occurrences. Therefore, rare taxa were not removed from the dataset, and tolerances were calculated for all 240 OTUs.

A taxon's WA fine sediment tolerance is the average of all \%FN for stream reaches in which the taxon was found, weighted by the taxon's abundance in each sample (WA regression) (Birks et al., 1990). Tolerances were then used to develop models (WA calibration) for inferring \% FN using macroinvertebrate samples only. A stream reach's \%FN was inferred as the average fine sediment tolerance of all taxa present in a sample, weighted by their respective abundances (Birks et al., 1990). Shrinkage of the range of inferred parameter values occurs in WA because averages are taken twice, once in the regression step and once in the calibration step (Birks et al., 1990). We used two methods to counteract for shrinkage and rescale the inferred values. With classical deshrinking, the initial inferred value $\left(\% \mathrm{FN}_{\text {init }}\right.$ ) is regressed on the observed (field measured) \%FN of the calibration set. For inverse deshrinking, the observed \%FN is regressed on the initial inferred (\%FN init $_{\text {) }}$ (Ter Braak and van Dam, 1989). Models using both types of deshrinking were generated and evaluated (see below).

To meet WA assumptions of unimodal response-curves (ter Braak and Looman, 1986), biological and environmental data were transformed prior to WA regression and calibration. Macroinvertebrate abundances were log transformed. Percent FN, which showed a highly left-skewed distribution (range $=0-98 \%$, median $=7 \%$ ), was transformed using the following equation:

$\% \mathrm{FN}_{\text {trans }}=\log 10\left(\left(\left(\arcsin \sqrt{\frac{\% \mathrm{FN}}{100}}\right)\left(\frac{2}{\pi}\right)\right)+1\right)$

Inference model performances were assessed by evaluating the root mean-squared error (RMSE) and coefficient of determination $\left(r^{2}\right)$ of the observed versus inferred values for \%FN. Because the inferred value of \%FN for a site was included in the CAL dataset, the apparent $r^{2}$ for observed versus inferred values may not be realistic for assessing the predictive power of the models to novel datasets (Cumming et al., 1995; Reavie et al., 1995). Therefore, cross 


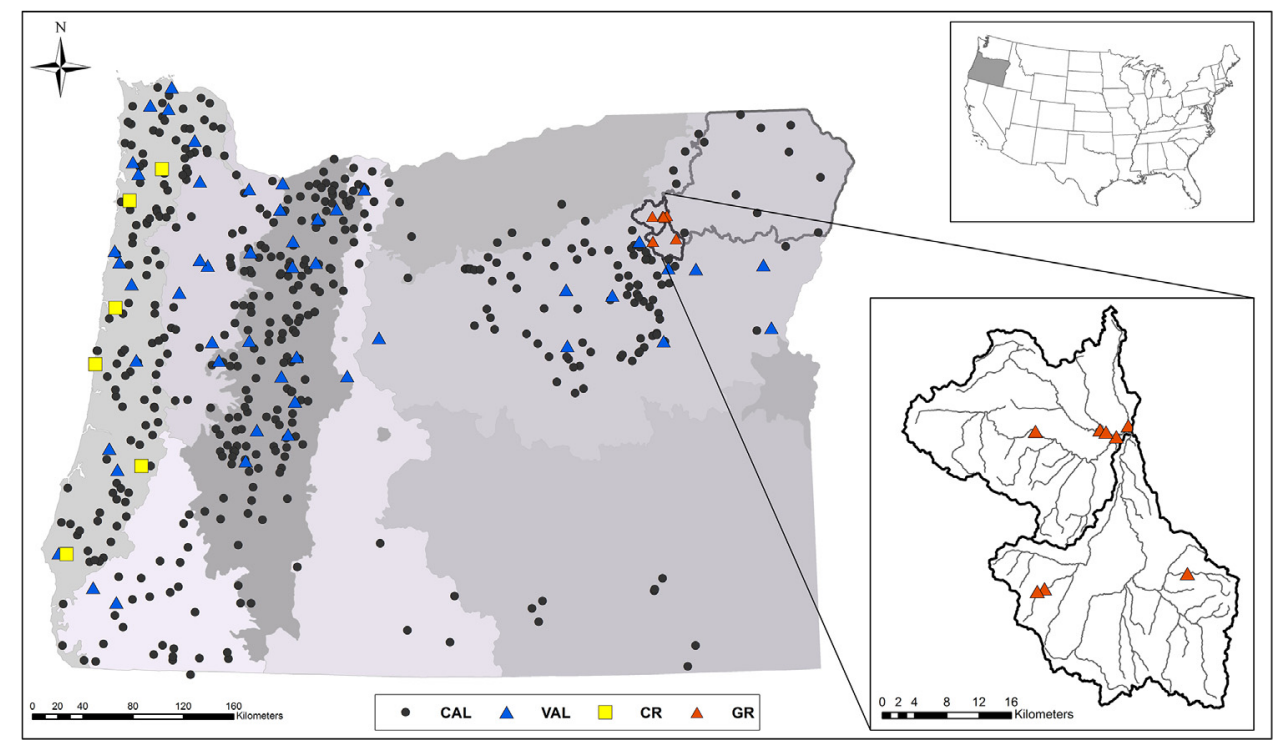

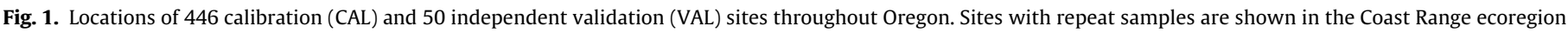
$(\mathrm{CR}, n=6)$ and Upper Grande Ronde Basin $(\mathrm{GR}, n=8)$. Shaded areas represent Oregon's nine Level III ecoregions and the Grande Ronde Basin is outlined.

validation with leave-one-out jackknifing and independent validation (VAL) were used to confirm the apparent $r^{2}$ (ter Braak and Juggins, 1993). Jackknifing infers the environmental value for a site by using all the sites except the inferred site to derive an estimated value, thereby avoiding possible circularity in the model evaluations. Maximum bias, calculated as the largest absolute value of mean bias for 10 equal parts of the environmental sampling interval, was used to evaluate systematic model error (ter Braak and Juggins, 1993). Models that produced low RMSE, high $r^{2}$, and low maximum bias were considered better models, with the greatest emphasis placed on results of the VAL dataset.

Inferred fines were converted to the BSTI by back-transforming the final (post deshrinking) inferred values $\left(\% \mathrm{FN}_{\text {inf }}\right)$ :

BSTI $=\left[\operatorname{sine}\left(\frac{\pi\left(10^{\left(\% \mathrm{FN}_{\text {inf }}\right)}-1\right)}{2}\right)\right]^{2} * 100$

When untransformed in this manner, the BSTI is on the same scale as \%FN.

\subsection{Estimating variability with repeated sampling}

We examined variability in BSTI from sites in Oregon's Coast Range Ecoregion (Omernik, 1987) and the upper Grande Ronde Basin (Fig. 1). These sites were chosen because they were sampled frequently across the years 1999-2009, as well as represented two different geographic regions and spatial scales. In the Coast Range, a total of 65 macroinvertebrate samples were collected across six sites. Sites in the Coast Range were part of a larger study with a random sampling design (ODEQ 2005), with these annually repeated sites established for estimates of variability.

In the Grande Ronde, eight sites were sampled a total of 122 times. Sites in the Grande Ronde were selected as part of a long term study on the effectiveness of cattle exclusion and stream channel restoration (Whitney, 2007). In 1968 and 1977, McCoy Creek was relocated, straightened, and channelized to increase grazing capacity and production. Restoration activities began with cattle exclusion beginning in 1988, then in 1997 the stream was returned to its natural channel for a $0.8 \mathrm{~km}$ stretch (McCoy Creek-Lower). The other sites included here were selected as different types of controls. All Grande Ronde sites were located in the Blue Mountains Ecoregion (Omernik, 1987).
For both projects, not all sites were sampled in each year, with sample sizes ranging from 6 to 22 within a site. Samples represented a mixture of same-day duplicates, seasonal repeats, and inter-annual visits. We calculated BSTI summary statistics and 95\% confidence intervals for each site, across all samples. In addition to natural gradients that are typically correlated with fine sediments, we also show quantified levels of human disturbances summed across the survey reach and at the watershed scale (Human Disturbance Index; Drake, 2004).

\subsection{Example application of the BSTI in Oregon}

To show the utility and cost-effective nature of the BSTI as a tool for assessing fine sediment conditions, we queried the Oregon Department of Environmental Quality (ODEQ) biomonitoring database for all records available to assess fine sediments across the state. Fine sediment conditions within 6 th field hydrologic unit codes (HUCs) were determined by calculating averages for both field measured (\%FN) and macroinvertebrate inferred (BSTI) fine sediments.

\section{Results}

\subsection{Comparisons between the calibration and validation datasets}

Overall, CAL and VAL datasets were similar for \%FN and other habitat and environmental variables (Fig. 2). The distributions of \%FN were similar between the CAL and VAL datasets, although minor differences were observed. VAL showed a slightly higher range (0-98\%FN) compared to CAL (0-93\%FN). VAL also showed slightly higher median (9\%FN) compared to CAL (7\%FN). Climate variables (precipitation and air temperature), canopy cover, and human disturbances were all quite similar between CAL and VAL.

From a stream size standpoint, the only substantial differences observed were due to one larger stream in the VAL, with a mean width two-times greater and a catchment area six-times greater than the maximum values represented in the CAL. The distributions of stream slopes were similar across the datasets, except for five samples in CAL that were beyond the maximum slope observed in VAL. Of all the variables examined between CAL and VAL, the greatest differences were observed in elevation. Median elevations 

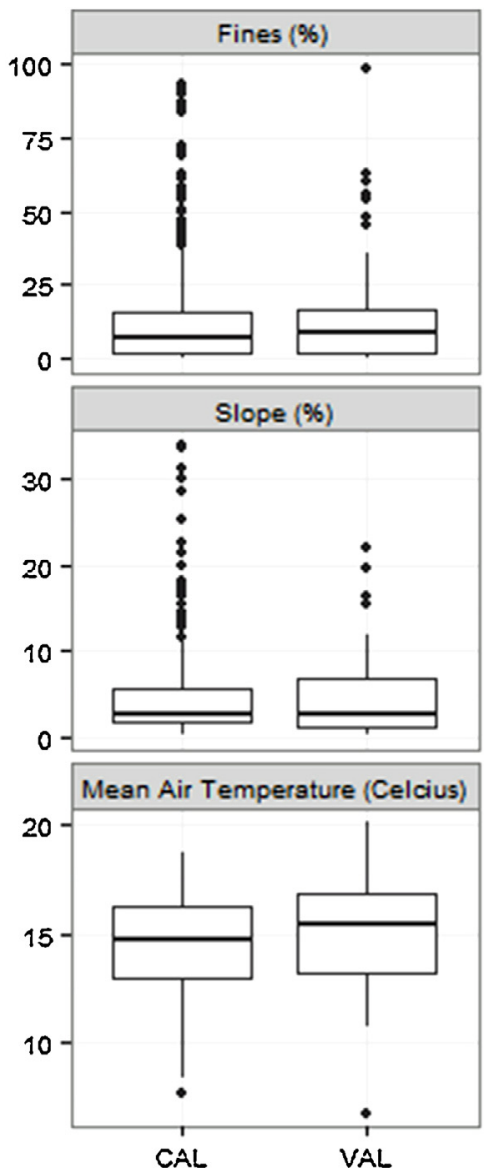
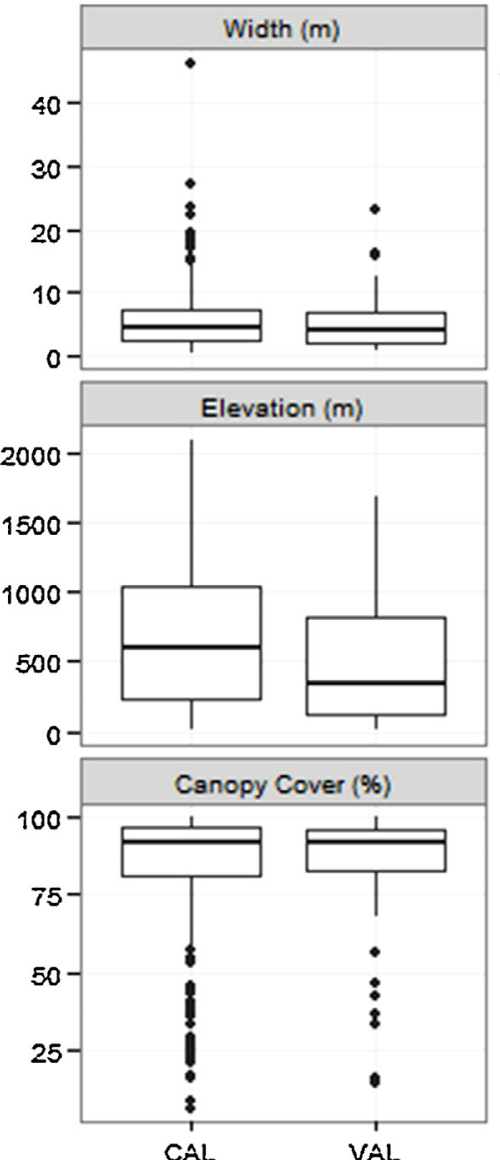

Dataset
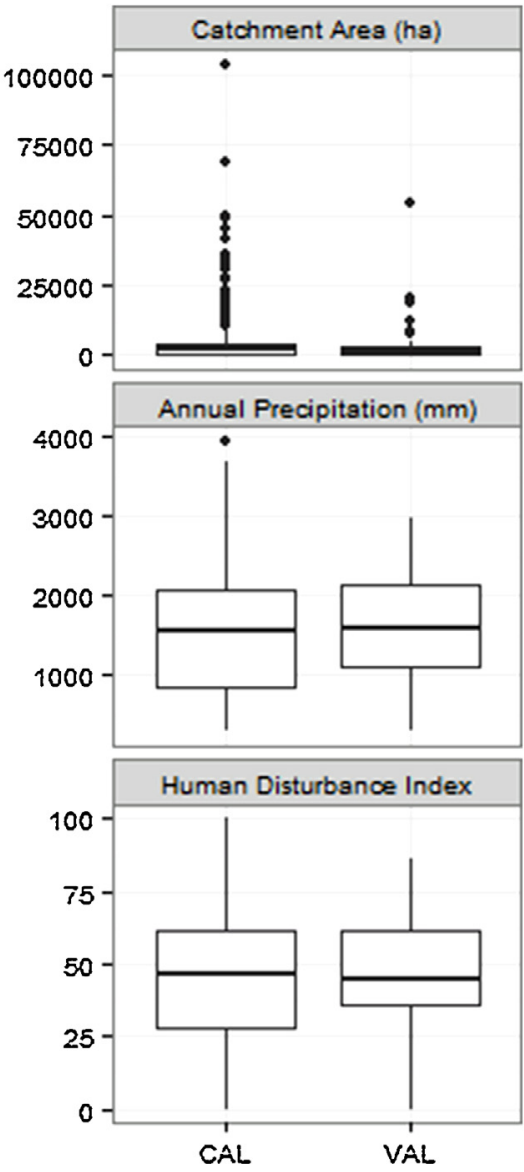

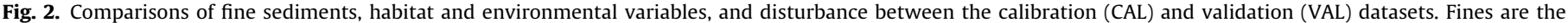
percent of substrate $<0.06 \mathrm{~mm}$ in diameter (\%FN). A single outlier was removed from the VAL dataset in the Catchment Area plot (618,694 ha).

were almost two-times greater in CAL, with higher quartile and maximum values than observed in VAL; although CAL also showed a lower minimum elevation.

\subsection{Tolerances across taxonomic groups}

The greatest number of tolerances were calculated for Trichoptera taxa $(n=69)$, followed by Diptera $(n=48)$, Ephemeroptera $(n=38)$, and Plecoptera $(n=36)$. The fewest number of taxa were observed for the taxa categorized as Insect-Other $(n=7)$. Tolerances across all 240 taxa ranged from 0 to $73 \% \mathrm{FN}$, with an average tolerance of 10\%FN. Taxa from the orders Ephemeroptera, Plecoptera, and Trichoptera (together: EPT) generally showed lower tolerances to fine sediments than taxa from other orders (Fig. 3). All three EPT orders had median tolerances of 6\%FN, and relatively few taxa with tolerances above $10 \%$ FN. Non-Insect and Insect-Other (the latter comprised of taxa within the orders Odonata and Megaloptera) showed the highest tolerances to fine sediments, with median

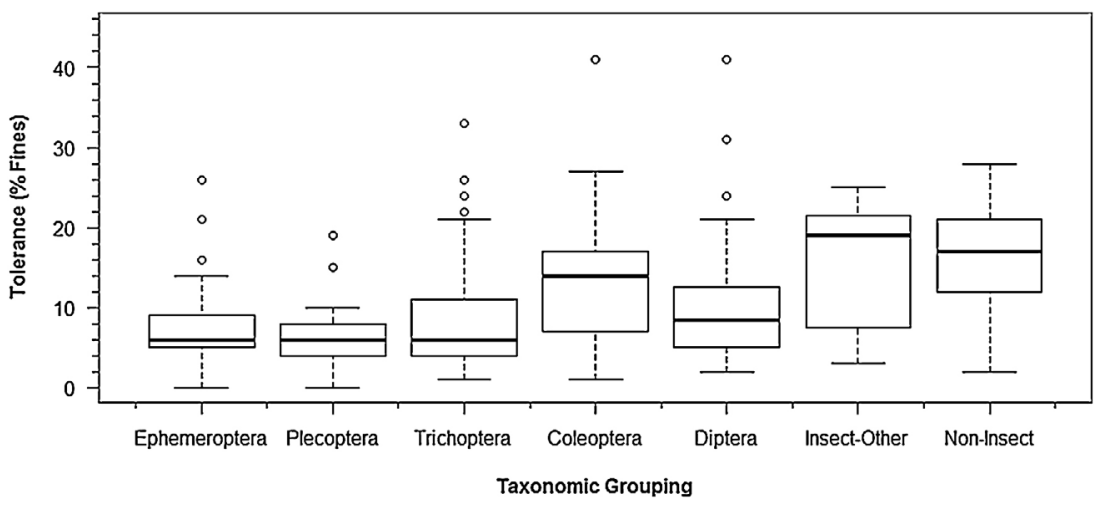

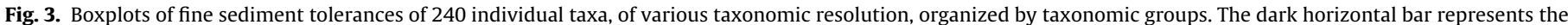

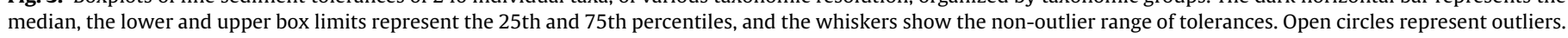
Two outliers were removed: Ephemeroptera (63\%), Non-Insect (73\%). 
Table 1

Root mean squared errors (RMSE), coefficient of determination $\left(r^{2}\right)$, bias estimates, and linear regression coefficients for inferred versus observed values across different sediment weighted averaging (WA) models. RMSE and bias units are in percent fine sediments (diameter $<0.06 \mathrm{~mm}$ ). Maximum bias is a measure of systematic error in the inferences (ter Braak and Juggins, 1993).

\begin{tabular}{lcc}
\hline & WA & WA \\
& Inverse deshrinking & Classic deshrinking \\
\hline Calibration RMSE & 2 & 4 \\
Jackknifed RMSE & 3 & 5 \\
Independent validation & 14 & 19 \\
RMSE & & \\
Training $r^{2}$ & 0.49 & 0.49 \\
Jackknifed $r^{2}$ & 0.41 & 0.42 \\
Independent validation & 0.58 & 0.52 \\
$r^{2}$ & & \\
Training max bias & 13 & 2 \\
Jackknifed max bias & 16 & 5 \\
Independent validation & 19 & 22 \\
max bias & & \\
Y-intercept & 0.037 & 0.00 \\
Slope & 0.482 & 1.00 \\
\hline
\end{tabular}

values of $17 \% \mathrm{FN}$ and $19 \% \mathrm{FN}$, respectively. Across all groups, very few taxa had tolerances above $20 \%$ FN.

\subsection{Weighted averaging model performance}

Differences among the WA modeling options were minimal. WA with inverse deshrinking was chosen for the final BSTI because it showed the lowest RMSE (14\% fines), highest $r^{2}(0.58)$, and lowest maximum bias (19\%) in the VAL dataset (Table 1). Errors (RMSE) in VAL were substantially higher than observed in CAL (2\%) and jackknifed (3\%) datasets. Inferences of \%FN tended to be overestimated when observed \%FN were low, and underestimated when observed \%FN were high (Fig. 4). This was true for both CAL and VAL, which had linear regressions with similar slopes.

The final inverse deshrinking equation was:

$\% \mathrm{FN}_{\text {pred }}=-0.312236+5.37189 * \% \mathrm{FN}_{\text {init }}$

\subsection{Repeatability of the BSTI}

Repeated measurements of the BSTI for six sites in the Coast Range Ecoregion and eight sites in the Grande Ronde Basin are shown in Table 2. Within the Coast Range, four of the six sites had median BSTIs of $10 \%$ or less and maximums less than $15 \%$. The $95 \%$ confidence intervals for the five sites with low BSTIs ranged from $1-3 \%$. Two of the sites (Montgomery and Tillamook) had median BSTIs near $30 \%$, and maximums of $36-42 \%$, respectively. These two sites also showed higher variability, with $95 \%$ confidence intervals approaching 8-9\%.

In the Upper Grande Ronde Basin, median BSTI values ranged from $6-24 \%$, with four of the eight sites showing a median BSTI below 10\%. Maximum BSTIs in the Grande Ronde sites ranged from 9-29\%. Variability in BSTI across all eight sites in the Grande Ronde was lower than that observed in the Coast Range, with 95\% confidence intervals from 1-3\%. We observed the highest BSTIs in the stream with active restoration (McCoy Creek-Lower), with a 57\% increase in mean BSTI compared to the upstream control (McCoy Creek-Upper).

\subsection{Estimating fine sediments using field observations and macroinvertebrate inferences}

From ODEQ's biomonitoring database, we calculated average fine sediment conditions in 6th field hydrologic unit codes (HUCs) across Oregon. We observed a total of 803 sites with direct measurements of fine sediments, representing 407 HUCs, with an average sample size of 2.0 in each HUC (Fig. 5A). In contrast, assessing fines using macroinvertebrate tolerances tripled the total sample size $(n=2536)$, doubled the number of watersheds assessed $(n=817)$, and increased the average number of samples per watershed to 3.1 (Fig. 5B).

From a statewide perspective, the assessment of conditions between field measured and biologically inferred fine sediments was similar, although minor differences were observed. The BSTI showed a slightly compressed range $(0-88 \%)$ compared to \%FN (0-100\%). Median BSTI (9\%) was slightly higher than median $\%$ FN (7\%), although means were nearly identical (13\% and $14 \%$, respectively). Comparisons among the condition bins in Fig. 5 also displayed minor differences. The BSTI showed a moderately lower percentage of watersheds in the $0-10 \%$ class $(55 \%)$, compared to $64 \%$ for \%FN. Conversely the BSTI had a moderately higher percentage of watersheds in the 11-20\% class than $\%$ FN (26\% and 15\%, respectively) (Fig. 5). Results were similar at the upper end of percent fines, with the BSTI resulting in $10 \%$
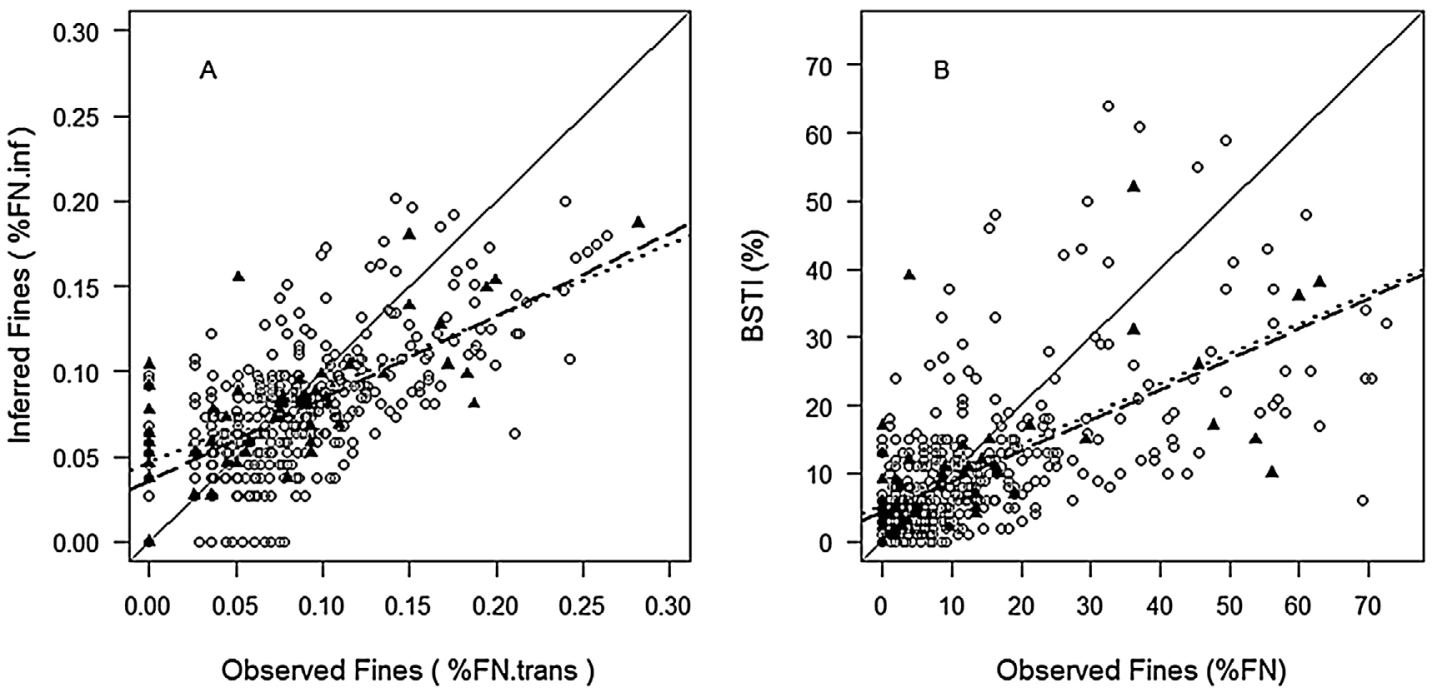

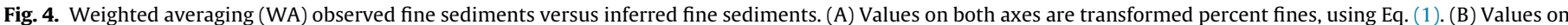

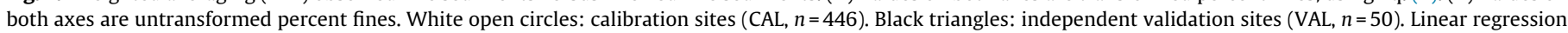
lines are shown for CAL (dashed) and VAL (dotted). The solid line is a 1:1 line. 
Table 2

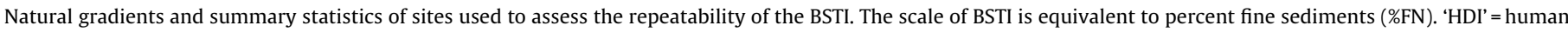
disturbance index, ' $n$ ' = sample size, ' $\mathrm{Cl}$ ' = confidence interval.

\begin{tabular}{|c|c|c|c|c|c|c|c|}
\hline Stream name & Site type & Erodible lithology in watershed (\%) & Slope (\%) & $\mathrm{HDI}^{\mathrm{a}}$ & $n$ & Median BSTI (range) & Mean BSTI $( \pm 95 \% \mathrm{CI})$ \\
\hline \multicolumn{8}{|l|}{ Coast Range } \\
\hline Ben Smith Creek & Random repeat & 42 & 7.3 & 51 & 16 & $5 \%(3-8)$ & $5 \%( \pm 1)$ \\
\hline Big Creek & Random repeat & 24 & 0.5 & 16 & 17 & $8 \%(4-12)$ & $8 \%( \pm 1)$ \\
\hline Montgomery Creek & Random repeat & 93 & 3.0 & 75 & 6 & $31 \%(19-36)$ & $29 \%( \pm 8)$ \\
\hline Sixes River & Random repeat & 98 & 0.3 & 43 & 10 & $10 \%(7-15)$ & $11 \%( \pm 2)$ \\
\hline Tillamook River & Random repeat & 79 & 0.1 & 79 & 9 & $29 \%(6-42)$ & $27 \%( \pm 9)$ \\
\hline Wolf Creek & Random repeat & 97 & 0.8 & 64 & 7 & $10 \%(9-12)$ & $10 \%( \pm 1)$ \\
\hline \multicolumn{8}{|l|}{ Grande Ronde Basin } \\
\hline Dark Canyon Creek & Negative control & 1 & 2.2 & 69 & 10 & $13 \%(8-21)$ & $14 \%( \pm 3)$ \\
\hline Limber Jim Creek-lower & Least disturbed & 47 & 3.4 & 36 & 22 & $9 \%(5-12)$ & $8 \%( \pm 1)$ \\
\hline Limber Jim Creek-upper & Least disturbed & 47 & 1.8 & 38 & 12 & $6 \%(3-14)$ & $7 \%( \pm 2)$ \\
\hline Lookout Creek & Least disturbed & 47 & 1.8 & 37 & 12 & $8 \%(3-9)$ & $7 \%( \pm 1)$ \\
\hline McCoy Creek-lower & Treatment & 1 & 0.9 & 69 & 17 & $24 \%(9-29)$ & $22 \%( \pm 3)$ \\
\hline McCoy Creek-upper & Upstream control & 1 & 0.7 & 69 & 17 & $13 \%(8-21)$ & $14 \%( \pm 2)$ \\
\hline Meadow Creek-lower & Positive control & 1 & 0.8 & 69 & 18 & $11 \%(3-19)$ & $11 \%( \pm 2)$ \\
\hline Meadow Creek-upper & Positive control & 1 & 1.0 & $\mathrm{n} / \mathrm{a}$ & 14 & $9 \%(6-12)$ & $9 \%( \pm 1)$ \\
\hline
\end{tabular}

a Higher values (unitless) represent increased human disturbances in the study reach and watershed (Drake, 2004).
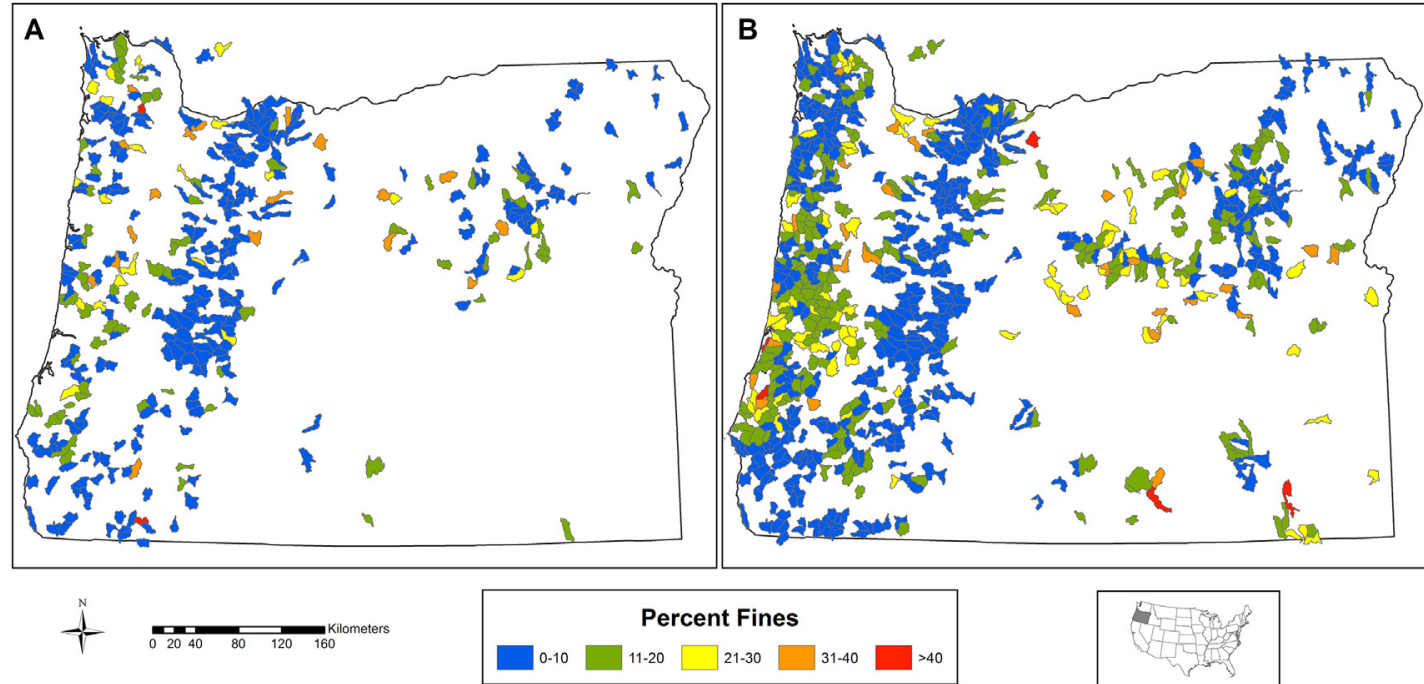

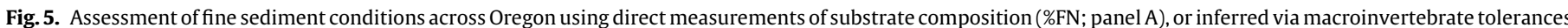
(BSTI; panel B). Each watershed is a 12-digit Hydrologic Unit Code (6th field). Condition bins represent averages of all samples in a watershed.

of watersheds and \%FN with $15 \%$ of watersheds above the $30 \%$ category.

\section{Discussion}

\subsection{Fine sediment particle sizes}

To our knowledge, our study represents the first efforts to infer fine sediment conditions in streams based on macroinvertebrate tolerances to the smallest bedded substrate particle sizes (silt and clay; median diameter $<0.06 \mathrm{~mm}$ ). It should be noted that given the visual nature of our field methods it was not possible to verify the size of particles classified as fines. As such, the actual particle sizes used in estimating \%FN are likely to include larger sizes. The substrate utilized by stream invertebrates includes both surface and subsurface habitat, thus the lack of information about subsurface sediment size classes presents an important limitation of this study. However, vertical stratification of the substrate typically results with finer sediment in the subsurface than the surface (Bunte and Abt, 2001), therefore surface estimates may be an underestimate of subsurface fines.
Yuan (2007), Relyea et al. (2012), and Murphy et al. (2015) each developed similar models or indices of macroinvertebrate tolerances to fine sediments, but all of these indices were calibrated on larger particles sizes $(<2 \mathrm{~mm}$; \%SAFN). There is evidence that the smallest particles sizes, such as \%FN in this study, show as much or perhaps more of an effect on macroinvertebrates than the larger particles sizes used in similar models (Runde and Hellenthal, 2000; Kaller and Hartman, 2004; Wood et al., 2005). Given that across Oregon we routinely observe a higher extent of wadeable streams exceeding thresholds for \%FN compared to \%SAFN (Hubler, 2007; Mulvey et al., 2009), we feel it is important to have a tool that addresses the most common and most likely stressor.

But, that is not to say that fine sediment sizes greater than modeled in our study may not impact macroinvertebrates. What becomes clear when reviewing the literature is that responses across varying size classes of fine sediments are taxon specific (Wood et al., 2005; Cover et al., 2008; Jones et al., 2012). Indices such as the BSTI that integrate taxon-specific responses to a stressor across the entire assemblage (Extence et al., 2013; Murphy et al., 2015) thus may offer increased sensitivity over the more traditional approaches, such as richness or relative abundances of indicator taxa. 


\subsection{BSTI model performance}

The performance of the BSTI compares favorably to similar inference models for stream macroinvertebrates. The jackknife estimated $r^{2}$ of the BSTI $(0.41$, Table 1$)$ was at the low end of that reported for macroinvertebrate WA pH models in Northern European streams $\left(r^{2}=0.47-0.71\right)$ (Hamalainen and Huttunen, 1996; Larsen et al., 1996). The most direct comparisons are to fine sediment inference models for streams across the Western U.S. (Yuan, 2007). Yuan reported a WA $r^{2}$ of 0.41 and a ML $r^{2}$ of 0.42 for observed versus inferred fine sediments in the calibration set, while in our study the BSTI showed a CAL $r^{2}$ of 0.49 . However, Yuan defined fine sediments as those particles with intermediate diameters less than $2 \mathrm{~mm}$ (\%SAFN). One possible explanation for this modest improvement of the BSTI over Yuan's models could be higher precision estimates in field measurements for \%FN, compared to \%SAFN (Kaufmann et al., 1999; Stoddard et al., 2005). The correlative abilities of two macroinvertebrate fine sediment diagnostic indices developed for Europe (Turley et al., 2014; Murphy et al., 2015) were similar to the predictive abilities of the BSTI.

The majority of environmental inference models assess model performance from the calibration dataset itself and some form of cross-validation (e.g., leave-one-out jackknifing or bootstrapping). Few studies have examined model performance using independent validation datasets (Ter Braak and van Dam, 1989; Birks et al., 1990; Telford et al., 2004; Telford and Birks, 2011). Similar to our results, in each of these studies estimates of model errors (RMSE) based on the calibration datasets were consistently lower than observed in independent datasets. Birks et al. (1990) split their original calibration dataset into different calibration and independent validation datasets of varying sample sizes. They observed an increase in RMSE in the independent validation datasets for six models, and a decrease in validation RMSE for four models. This would indicate that final estimates of model performance can be influenced by the composition of the individual sites selected for any independent validation dataset. The multiple-trials approach used by Birks et al. (1990) and Telford et al. (2004) may provide a more accurate assessment of model performance than relying on a single validation dataset. However, this would require multiple versions of the inference model, which could make implementation within a management setting more complicated.

An additional consideration for future improvements of the BSTI centers on taxonomic resolution. Currently, $18 \%$ of taxa used in construction of the BSTI were identified to higher levels (less resolution) than genus or species. Turley et al. (2014) showed taxonomic resolution can have minor to modest effects on relationships between a biological index and the stressor of interest. However, typically improvements are observed. While it is unlikely to see taxonomic advances in groups of taxa routinely left at less resolved levels (e.g., Order, Class, etc.), there are already substantial advances within certain groups. Most specifically, the Chironomidae are widely recognized as a highly diverse family. Since the early to mid2000s, standardized taxonomy in the PNW now routinely identifies the Chironomids to genus or species. These efforts, as well as efforts to standardize taxonomic levels for all taxa across PNW monitoring programs (PNAMP, 2015) should work to improve future versions of the BSTI. On the other hand, Juggins et al. (2015) showed inference model improvements when non-informative taxa were excluded. Incorporating methods to determine non-informative taxa may lead to model improvements.

\subsection{Repeatability of the BSTI}

Few studies have examined the repeatability of biological inference models of environmental gradients, such as the BSTI. Hamalainen and Huttunen (1996) calibrated their macroinvertebrate $-\mathrm{pH}$ inference models with 64 sites, sampled three times in a single year. Ponader et al. (2007) included repeated samples in the development of diatom-based nutrient inference models for New Jersey streams, finding that exclusion of the repeat samples did not significantly decrease model performance. However, neither of these studies examined the repeatability of the models across sites.

Our examination of repeat data shows the BSTI can make precise inferences for a site, with a degree of independence from natural gradients that may influence fine sediments levels in streams. These results may give an indication of the suitability of the BSTI as a bioassessment tool for detecting human disturbances at a site, when placed in context with these natural gradients (see management discussion, below). For example, in the Coast Range we observed the highest BSTI values and variability for Montgomery Creek and Tillamook River (Table 2). Both sites contain high percentages of erodible lithology in their watersheds, which would be expected to increase fine sediments. But Montgomery Creek had the second highest stream gradient in the Coast Range, which would be expected to decrease sedimentation by increased stream power (Wood and Armitage, 1997). On the other hand, these two sites had the highest human disturbance values of all 14 repeat sites. Conversely, the Sixes River site had two natural gradients typically associated with higher sedimentation (high erodibility and low slope) and one gradient associated with lower sedimentation (high rainfall = increased stream power); yet the Sixes showed moderate BSTIs ( $11 \pm 2 \%$; Table 2 ). In the Grande Ronde, we observed the lowest BSTIs for the three sites (both Limber Jim Creek sites and Lookout Creek) with the highest potential source material (high erodibility); but these three sites conversely had the highest slopes and precipitation. Incidentally, these sites also showed the lowest degrees of human disturbance across the study area. The highest fine sediment inferences in the Grande Ronde were observed in the restoration site, McCoy Creek-Lower. This result is unsurprising, given that the restoration action was to return the creek from a heavily channelized section back into the previously abandoned natural channel which had a lower slope, higher sinuosity, and had accumulated fine sediments over the years. Similar to observations in the Coast Range, the two sites with the greatest degree of human disturbances in the Grande Ronde (Dark Canyon and McCoy-Lower), showed increased variability (although minor) in BSTI.

\subsection{Management implications}

Clearly, excess sedimentation is a global issue (Chutter, 1969; Ryan, 1991; Wood and Armitage, 1997; Paulsen et al., 2008); but resource management efforts to address the impacts caused by fine sediments above natural background levels must be dealt with at local scales. Larger, regional scale biotic-fine sediment indexes have been developed for the Western United States (Yuan, 2007) and the PNW (Relyea et al., 2012), but these indexes lack the density of sampling locations necessary to adequately represent a management area as environmentally heterogeneous as Oregon (Omernik, 1987). Thus, we focused on development of an index with the greatest utility in identifying potential stream impairments in Oregon.

The BSTI provides an alternative, robust, and cost-effective approach to monitoring fine sediment conditions across Oregon. The shared macroinvertebrate field methods across resource agencies in the PNW and the increased ability to engage citizenbased monitoring groups provides an opportunity to substantially increase our assessments of fine sediment conditions. As an example of the cost-effective nature of the BSTI, we queried the Oregon Department of Environmental Quality (ODEQ) biomonitoring database for all records available to assess fine sediments across the state (Fig. 5). While direct comparisons between the two 
datasets are not possible (due to spatial and temporal differences in monitoring), similar overall patterns are presented. However, the BSTI offers a clear advantage due to increased sample size, filling in gaps in the Coast Range (far left), Northeastern Oregon, and (to a lesser extent) Southeastern Oregon. Most importantly, approximately $43 \%$ of the BSTI scores were obtained from data sources outside of ODEQ. These partners represented nearly all monitoring organization types, from local citizen-based monitoring groups operating at watershed or basin scales, up to a broad-scale and long-term federal program that spanned multiple PNW states. All of these external datasets were capable of integration within ODEQ's program due to the foresight of resource managers to align sampling and laboratory methods for macroinvertebrate monitoring (Hayslip, 2007). Unfortunately, similar efforts to align physical habitat protocols have had minimal traction.

While the BSTI demonstrated a good ability to infer instream fine sediment conditions with high repeatability, we feel the greatest stream management utility would be within a reference condition approach (Bailey et al., 1998, 2004; Reynoldson and Wright, 2000). Reference expectations for BSTI scores at any study site would be based on the distribution of BSTI scores observed at a population of least disturbed (Stoddard et al., 2006) reference sites. Here, standard biointegrity indices like Observed/Expected taxa (O/E; Wright et al., 1993; Hawkins et al., 2000) or Indices of Biotic Integrity (Karr, 1981; Karr, 1991; Rehn et al., 2007) could be used to identify biological impairment, and then the BSTI could be used to identify excess fine sediments as a likely cause of the biological impairment. While reference expectations are built into O/E and IBI indexes, they are not integrated into WA inferences of environmental gradients, such as the BSTI. (The rationale for this is that not all taxa are observed at reference sites, especially the most tolerant taxa.) As shown in the sites with repeat sampling, BSTI values can show a complex relationship between natural environmental gradients and human disturbances. Future efforts to integrate the use of the BSTI into a reference condition approach should therefore address the need to factor out natural gradients from reference expectations. Until that time, the bins shown in Fig. 5 may provide interim guidelines for assessing conditions, with BSTIs less than $10 \%$ indicating little to no fine sediment impairment and BSTIs greater than 30 indicating moderate to severe impairment.

There is a wide range of possibilities in how the BSTI, or similar indexes that explicitly infer stressor gradients using biota, could be used in a stream management setting. Anyone wishing to calculate the BSTI for their own data simply need to apply macroinvertebrate abundances and the tolerances in Appendix to the weighted averaging and inverse deshrinking formulas presented by Ter Braak and van Dam (1989) and Birks et al. (1990), followed by the back-transformation step provided in Eq. (2). Sites lacking measured fine sediment data and high BSTI values (on the scale of \% fine sediments) could be prioritized within monitoring plans for more technical sediment field studies to confirm whether or not the instream conditions match those inferred by the macroinvertebrate assemblage (e.g., Turley et al., 2014). Or BSTI reference benchmarks could be used by resource managers as targets within total maximum daily loads (TMDLs) (Karr and Yoder, 2004; Yagow et al., 2006), representing desired shifts in the protected biological assemblage toward more natural conditions. Citizen-based monitoring groups could use expected BSTI scores to assess the effectiveness of restoration projects, such as additions of large woody debris or decommissioning of failing road networks to improve instream sediment conditions. In this example, a stream with a high degree of excess fine sediments could be monitored to see if the assemblage-level tolerance to fine sediments decreased following implementation of the restoration actions.

\section{Acknowledgements}

We would like to thank the field crews that collected the data used in this paper. Adam Thompson, Ryan Michie, and Peter Bryant, provided valuable manuscript reviews. We thank Lesley Merrick for GIS support. Funding sources for the survey data used in this paper included the United States Environmental Protection Agency's Environmental Monitoring and Assessment ProgramWestern Pilot, the Oregon Plan for Salmon and Watersheds, and the Grande Ronde Section 319 National Monitoring Program Project. External data sources were provided by Chuck Hawkins, Kara Anlauf-Dunn, Chris Prescott, the Rogue Basin Coordinating Council, and the Yamhill Watershed Council.

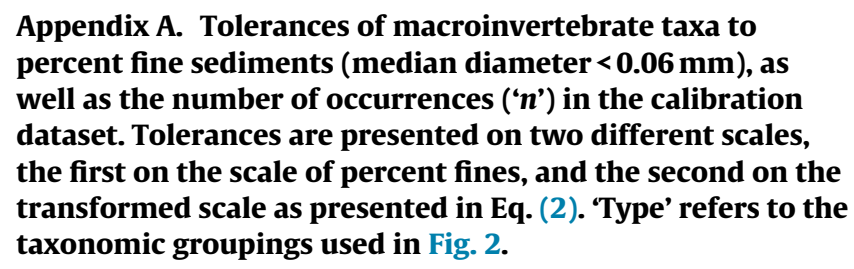

\begin{tabular}{|c|c|c|c|c|c|}
\hline Taxon & Type & Level & Count & Tolerance (\% FN) & Tolerance (transformed) \\
\hline Heptagenia & Ephemeroptera & Genus & 1 & 0 & 0 \\
\hline Prostoia & Plecoptera & Genus & 1 & 0 & 0 \\
\hline Neophylax occidentalis & Trichoptera & Species & 5 & 1 & 0.0214 \\
\hline Ordobrevia & Coleoptera & Genus & 37 & 1 & 0.0309 \\
\hline Plumiperla & Plecoptera & Genus & 8 & 2 & 0.0336 \\
\hline Pilaria & Diptera & Genus & 5 & 2 & 0.0344 \\
\hline Sierraperla & Plecoptera & Genus & 2 & 2 & 0.0348 \\
\hline Diamesinae & Diptera & Sub-Family & 1 & 2 & 0.0359 \\
\hline Podmosta & Plecoptera & Genus & 1 & 2 & 0.0359 \\
\hline Rhyacophila Oreta Gr. & Trichoptera & Species group & 1 & 2 & 0.0359 \\
\hline Soyedina & Plecoptera & Genus & 1 & 2 & 0.0359 \\
\hline Valvata & Non-Insect & Genus & 1 & 2 & 0.0367 \\
\hline Oligophlebodes & Trichoptera & Genus & 31 & 2 & 0.0383 \\
\hline Arctopsyche & Trichoptera & Genus & 72 & 2 & 0.0396 \\
\hline Cryptochia & Trichoptera & Genus & 24 & 2 & 0.0396 \\
\hline Agraylea & Trichoptera & Genus & 7 & 2 & 0.0397 \\
\hline Allocosmoecus & Trichoptera & Genus & 4 & 2 & 0.0407 \\
\hline Ochrotrichia & Trichoptera & Genus & 14 & 2 & 0.041 \\
\hline Epeorus grandis & Ephemeroptera & Species & 90 & 2 & 0.0415 \\
\hline Acneus & Coleoptera & Genus & 10 & 2 & 0.0416 \\
\hline Kathroperla & Plecoptera & Genus & 26 & 3 & 0.0419 \\
\hline Blephariceridae & Diptera & Family & 19 & 3 & 0.0423 \\
\hline Epeorus deceptivus & Ephemeroptera & Species & 11 & 3 & 0.0428 \\
\hline Soliperla & Plecoptera & Genus & 33 & 3 & 0.043 \\
\hline
\end{tabular}




\begin{tabular}{|c|c|c|c|c|c|}
\hline Taxon & Type & Level & Count & Tolerance (\% FN) & Tolerance (transformed) \\
\hline Rhyacophila Hyalinata Gr. & Trichoptera & Species group & 136 & 3 & 0.0434 \\
\hline Rhyacophila Iranda Gr. & Trichoptera & Species group & 11 & 3 & 0.0435 \\
\hline Ampumixis & Coleoptera & Genus & 59 & 3 & 0.0442 \\
\hline Petrophila & Insect-Other & Genus & 5 & 3 & 0.0447 \\
\hline Hesperoconopa & Diptera & Genus & 21 & 3 & 0.0451 \\
\hline Eubrianax edwardsi & Coleoptera & Species & 36 & 3 & 0.0454 \\
\hline Oreogeton & Diptera & Genus & 36 & 3 & 0.0464 \\
\hline Rhyacophila Nevadensis Gr. & Trichoptera & Species group & 4 & 3 & 0.0464 \\
\hline Drunella doddsi & Ephemeroptera & Species & 83 & 3 & 0.0471 \\
\hline Rhyacophila Angelita Gr. & Trichoptera & Species group & 74 & 3 & 0.0472 \\
\hline Ecclisomyia & Trichoptera & Genus & 19 & 3 & 0.0475 \\
\hline Philocasca & Trichoptera & Genus & 2 & 3 & 0.0479 \\
\hline Drunella grandis & Ephemeroptera & Species & 240 & 3 & 0.048 \\
\hline Polycentropodidae & Trichoptera & Family & 18 & 3 & 0.049 \\
\hline Visoka & Plecoptera & Genus & 109 & 4 & 0.0494 \\
\hline Nemoura & Plecoptera & Genus & 3 & 4 & 0.0495 \\
\hline Anagapetus & Trichoptera & Genus & 31 & 4 & 0.0498 \\
\hline Pteronarcys & Plecoptera & Genus & 112 & 4 & 0.0498 \\
\hline Caudatella & Ephemeroptera & Genus & 90 & 4 & 0.0502 \\
\hline Epeorus longimanus & Ephemeroptera & Species & 92 & 4 & 0.0504 \\
\hline Wiedemannia & Diptera & Genus & 10 & 4 & 0.0512 \\
\hline Megarcys & Plecoptera & Genus & 70 & 4 & 0.0513 \\
\hline Parapsyche elsis & Trichoptera & Species & 82 & 4 & 0.0514 \\
\hline Zapada frigida & Plecoptera & Species & 27 & 4 & 0.0514 \\
\hline Leucotrichia & Trichoptera & Genus & 4 & 4 & 0.0524 \\
\hline Rhyacophila Vagrita Gr. & Trichoptera & Species group & 14 & 4 & 0.0525 \\
\hline Neotrichia & Trichoptera & Genus & 6 & 4 & 0.0526 \\
\hline Rhyacophila Brunnea Gr. & Trichoptera & Species group & 221 & 4 & 0.053 \\
\hline Agapetus & Trichoptera & Genus & 51 & 4 & 0.0534 \\
\hline Pseudolimnophila & Diptera & Genus & 2 & 4 & 0.0536 \\
\hline Rhyacophila Vofixa Gr. & Trichoptera & Species group & 30 & 4 & 0.054 \\
\hline Drunella coloradensis/flavilinea & Ephemeroptera & Species & 134 & 4 & 0.0541 \\
\hline Acentrella insignificans & Ephemeroptera & Species & 9 & 4 & 0.055 \\
\hline Procloeon & Ephemeroptera & Genus & 2 & 5 & 0.0556 \\
\hline Rhithrogena & Ephemeroptera & Genus & 253 & 5 & 0.0556 \\
\hline Clinocera & Diptera & Genus & 73 & 5 & 0.0557 \\
\hline Zapada columbiana & Plecoptera & Species & 104 & 5 & 0.0557 \\
\hline Atherix & Diptera & Genus & 28 & 5 & 0.0558 \\
\hline Neophylax splendens & Trichoptera & Species & 67 & 5 & 0.0561 \\
\hline Perlinodes & Plecoptera & Genus & 15 & 5 & 0.0564 \\
\hline Rhyacophila Betteni Gr. & Trichoptera & Species group & 272 & 5 & 0.0566 \\
\hline Acentrella turbida & Ephemeroptera & Species & 36 & 5 & 0.0567 \\
\hline Pedomoecus & Trichoptera & Genus & 6 & 5 & 0.057 \\
\hline Pseudochironomini & Diptera & Tribe & 2 & 5 & 0.0572 \\
\hline Antocha & Diptera & Genus & 187 & 5 & 0.0575 \\
\hline Thaumalea & Diptera & Genus & 28 & 5 & 0.0588 \\
\hline Brachycentrus & Trichoptera & Genus & 40 & 5 & 0.0589 \\
\hline Claassenia sabulosa & Plecoptera & Species & 4 & 5 & 0.0591 \\
\hline Neophylax rickeri & Trichoptera & Species & 72 & 5 & 0.0591 \\
\hline Serratella tibialis & Ephemeroptera & Species & 170 & 5 & 0.0593 \\
\hline Cultus & Plecoptera & Genus & 18 & 5 & 0.0595 \\
\hline Drunella pelosa & Ephemeroptera & Species & 25 & 5 & 0.06 \\
\hline Rhyacophila Verrula Gr. & Trichoptera & Species group & 17 & 5 & 0.0603 \\
\hline Glossosoma & Trichoptera & Genus & 270 & 5 & 0.0604 \\
\hline Deuterophlebia & Diptera & Genus & 112 & 5 & 0.0605 \\
\hline Suwallia & Plecoptera & Genus & 25 & 5 & 0.0606 \\
\hline Apatania & Trichoptera & Genus & 71 & 6 & 0.0611 \\
\hline Calineuria & Plecoptera & Genus & 254 & 6 & 0.0612 \\
\hline Doroneuria & Plecoptera & Genus & 35 & 6 & 0.0616 \\
\hline Cordulegastridae & Insect-Other & Family & 1 & 6 & 0.0621 \\
\hline Neothremma & Trichoptera & Genus & 39 & 6 & 0.0622 \\
\hline Rhyacophila narvae & Trichoptera & Species & 132 & 6 & 0.0626 \\
\hline Baetis bicaudatus & Ephemeroptera & Species & 17 & 6 & 0.0632 \\
\hline Hydatophylax & Trichoptera & Genus & 10 & 6 & 0.0633 \\
\hline Rhyacophila Grandis Gr. & Trichoptera & Species group & 19 & 6 & 0.0636 \\
\hline Psephenus & Coleoptera & Genus & 22 & 6 & 0.0637 \\
\hline Baetis tricaudatus & Ephemeroptera & Species & 398 & 6 & 0.0641 \\
\hline Amiocentrus & Trichoptera & Genus & 56 & 6 & 0.0643 \\
\hline Maruina & Diptera & Genus & 52 & 6 & 0.0645 \\
\hline Timpanoga hecuba & Ephemeroptera & Species & 14 & 6 & 0.0645 \\
\hline Ironodes & Ephemeroptera & Genus & 176 & 6 & 0.0646 \\
\hline Ameletus & Ephemeroptera & Genus & 184 & 6 & 0.0647 \\
\hline Dicosmoecus gilvipes & Trichoptera & Species & 14 & 6 & 0.0647 \\
\hline Cinygmula & Ephemeroptera & Genus & 244 & 6 & 0.065 \\
\hline Hydropsyche & Trichoptera & Genus & 248 & 6 & 0.065 \\
\hline Baetis flavistriga & Ephemeroptera & Species & 17 & 6 & 0.0651 \\
\hline Drunella spinifera & Ephemeroptera & Species & 65 & 6 & 0.0651 \\
\hline Goeracea & Trichoptera & Genus & 1 & 6 & 0.0651 \\
\hline
\end{tabular}




\begin{tabular}{|c|c|c|c|c|c|}
\hline Taxon & Type & Level & Count & Tolerance (\% FN) & Tolerance (transformed) \\
\hline Forcipomyiinae & Diptera & Sub-Family & 62 & 6 & 0.0652 \\
\hline Serratella teresa & Ephemeroptera & Species & 20 & 6 & 0.0655 \\
\hline Rhyacophila pellisa/valuma & Trichoptera & Species & 50 & 6 & 0.0658 \\
\hline Yoraperla & Plecoptera & Genus & 190 & 6 & 0.0658 \\
\hline Rhabdomastix & Diptera & Genus & 21 & 7 & 0.0661 \\
\hline Palaegapetus & Trichoptera & Genus & 3 & 7 & 0.0662 \\
\hline Rhyacophila Alberta Gr. & Trichoptera & Species group & 16 & 7 & 0.0664 \\
\hline Hesperoperla pacifica & Plecoptera & Species & 176 & 7 & 0.0673 \\
\hline Heterlimnius & Coleoptera & Genus & 259 & 7 & 0.0674 \\
\hline Despaxia & Plecoptera & Genus & 4 & 7 & 0.0677 \\
\hline Kogotus/Rickera & Plecoptera & Genus & 14 & 7 & 0.068 \\
\hline Zapada Oregonensis Gr. & Plecoptera & Species group & 65 & 7 & 0.0681 \\
\hline Hemerodromia & Diptera & Genus & 17 & 7 & 0.0686 \\
\hline Micrasema & Trichoptera & Genus & 223 & 7 & 0.0688 \\
\hline Prosimulium & Diptera & Genus & 35 & 7 & 0.0699 \\
\hline Lepidostoma & Trichoptera & Genus & 195 & 7 & 0.07 \\
\hline Attenella & Ephemeroptera & Genus & 49 & 7 & 0.0702 \\
\hline Taeniopterygidae & Plecoptera & Family & 11 & 8 & 0.0707 \\
\hline Dicosmoecus atripes & Trichoptera & Species & 162 & 8 & 0.0708 \\
\hline Turbellaria & Non-Insect & Class & 158 & 8 & 0.071 \\
\hline Sweltsa & Plecoptera & Genus & 312 & 8 & 0.0717 \\
\hline Hexatoma & Diptera & Genus & 176 & 8 & 0.0721 \\
\hline Ecclisocosmoecus & Trichoptera & Genus & 11 & 8 & 0.0724 \\
\hline Glutops & Diptera & Genus & 124 & 8 & 0.0728 \\
\hline Tanytarsini & Diptera & Tribe & 426 & 8 & 0.073 \\
\hline Moselia & Plecoptera & Genus & 61 & 8 & 0.0733 \\
\hline Skwala & Plecoptera & Genus & 75 & 8 & 0.074 \\
\hline Chelifera/Metachela & Diptera & Genus & 165 & 8 & 0.0741 \\
\hline Simulium & Diptera & Genus & 303 & 8 & 0.0745 \\
\hline Epeorus albertae & Ephemeroptera & Species & 73 & 8 & 0.0746 \\
\hline Orthocladiinae & Diptera & Sub-Family & 444 & 8 & 0.0746 \\
\hline Trombidiformes & Non-Insect & Order & 383 & 9 & 0.075 \\
\hline Setvena & Plecoptera & Genus & 6 & 9 & 0.0751 \\
\hline Wormaldia & Trichoptera & Genus & 221 & 9 & 0.0755 \\
\hline Paraperla & Plecoptera & Genus & 35 & 9 & 0.0757 \\
\hline Ephemerella & Ephemeroptera & Genus & 97 & 9 & 0.076 \\
\hline Dicranota & Diptera & Genus & 53 & 9 & 0.0761 \\
\hline Narpus & Coleoptera & Genus & 109 & 9 & 0.0762 \\
\hline Zaitzevia & Coleoptera & Genus & 274 & 9 & 0.0763 \\
\hline Limonia & Diptera & Genus & 12 & 9 & 0.0766 \\
\hline Psychoda & Diptera & Genus & 2 & 9 & 0.0766 \\
\hline Baetis alius & Ephemeroptera & Species & 3 & 9 & 0.0784 \\
\hline Malenka & Plecoptera & Genus & 203 & 9 & 0.0786 \\
\hline Diphetor hageni & Ephemeroptera & Species & 250 & 9 & 0.0787 \\
\hline Gomphidae & Insect-Other & Family & 65 & 9 & 0.0788 \\
\hline Nixe/Leucocruta & Ephemeroptera & Genus & 55 & 10 & 0.079 \\
\hline Rhyacophila Rotunda Gr. & Trichoptera & Species group & 2 & 10 & 0.079 \\
\hline Baetis notos & Ephemeroptera & Species & 15 & 10 & 0.0791 \\
\hline Meringodixa & Diptera & Genus & 26 & 10 & 0.0797 \\
\hline Pericoma/Telmatoscopus & Diptera & Genus & 70 & 10 & 0.08 \\
\hline Chironomini & Diptera & Tribe & 260 & 10 & 0.0803 \\
\hline Capniidae & Plecoptera & Family & 33 & 10 & 0.0804 \\
\hline Leptoceridae & Trichoptera & Family & 6 & 10 & 0.081 \\
\hline Oligochaeta & Non-Insect & Class & 361 & 10 & 0.081 \\
\hline Gumaga & Trichoptera & Genus & 18 & 10 & 0.0813 \\
\hline Zapada cinctipes & Plecoptera & Species & 281 & 10 & 0.0817 \\
\hline Diura & Plecoptera & Genus & 278 & 10 & 0.0819 \\
\hline Tricorythodes & Ephemeroptera & Genus & 15 & 10 & 0.0823 \\
\hline Ephydridae & Diptera & Family & 11 & 10 & 0.0825 \\
\hline Labiobaetis & Ephemeroptera & Genus & 1 & 10 & 0.0827 \\
\hline Heteroplectron & Trichoptera & Genus & 14 & 11 & 0.0832 \\
\hline Paraleptophlebia & Ephemeroptera & Genus & 293 & 11 & 0.0836 \\
\hline Dixella & Diptera & Genus & 122 & 11 & 0.0839 \\
\hline Ceratopogoninae & Diptera & Sub-Family & 200 & 11 & 0.0842 \\
\hline Nematoda & Non-Insect & Phylum & 231 & 11 & 0.0855 \\
\hline Lara & Coleoptera & Genus & 105 & 11 & 0.0856 \\
\hline Odontoceridae & Trichoptera & Family & 4 & 11 & 0.0857 \\
\hline Tanypodinae & Diptera & Sub-Family & 279 & 12 & 0.0875 \\
\hline Optioservus & Coleoptera & Genus & 236 & 12 & 0.0876 \\
\hline Pristinicola & Non-Insect & Genus & 28 & 12 & 0.0877 \\
\hline Helicopsyche & Trichoptera & Genus & 15 & 12 & 0.0881 \\
\hline Ormosia & Diptera & Genus & 1 & 12 & 0.0895 \\
\hline Stratiomyidae & Diptera & Family & 9 & 12 & 0.0897 \\
\hline Rhyacophila Lieftincki Gr. & Trichoptera & Species group & 18 & 13 & 0.0909 \\
\hline Rhyacophila blarina & Trichoptera & Species & 58 & 13 & 0.0918 \\
\hline Dixa & Diptera & Genus & 5 & 13 & 0.0931 \\
\hline Podonominae & Diptera & Sub-Family & 8 & 13 & 0.0932 \\
\hline Psychoglypha & Trichoptera & Genus & 30 & 14 & 0.0936 \\
\hline
\end{tabular}




\begin{tabular}{|c|c|c|c|c|c|}
\hline Taxon & Type & Level & Count & Tolerance (\% FN) & Tolerance (transformed) \\
\hline Parapsyche almota & Trichoptera & Species & 39 & 14 & 0.094 \\
\hline Prostoma & Non-Insect & Genus & 6 & 14 & 0.0945 \\
\hline Limnophila & Diptera & Genus & 42 & 14 & 0.0948 \\
\hline Desmona & Trichoptera & Genus & 1 & 14 & 0.0949 \\
\hline Amphizoa & Coleoptera & Genus & 3 & 14 & 0.0954 \\
\hline Cryptolabis & Diptera & Genus & 9 & 14 & 0.0961 \\
\hline Psychomyia & Trichoptera & Genus & 10 & 15 & 0.0968 \\
\hline Hirudinea & Non-Insect & Class & 4 & 15 & 0.0973 \\
\hline Pteronarcella & Plecoptera & Genus & 19 & 15 & 0.0973 \\
\hline Juga & Non-Insect & Genus & 132 & 15 & 0.0986 \\
\hline Hydraena & Coleoptera & Genus & 27 & 15 & 0.0991 \\
\hline Ochthebius & Coleoptera & Genus & 5 & 15 & 0.0995 \\
\hline Fluminicola & Non-Insect & Genus & 32 & 16 & 0.0999 \\
\hline Cinygma & Ephemeroptera & Genus & 79 & 16 & 0.1 \\
\hline Cleptelmis & Coleoptera & Genus & 76 & 16 & 0.101 \\
\hline Hydrophilidae & Coleoptera & Family & 46 & 16 & 0.101 \\
\hline Rhyacophila Coloradensis Gr. & Trichoptera & Species group & 5 & 16 & 0.101 \\
\hline Goera & Trichoptera & Genus & 9 & 16 & 0.102 \\
\hline Metrichia & Trichoptera & Genus & 1 & 16 & 0.102 \\
\hline Tabanidae & Diptera & Family & 26 & 16 & 0.102 \\
\hline Ferrissia & Non-Insect & Genus & 14 & 17 & 0.103 \\
\hline Margaritifera & Non-Insect & Genus & 5 & 17 & 0.103 \\
\hline Ostracoda & Non-Insect & Class & 93 & 17 & 0.103 \\
\hline Hydroptila & Trichoptera & Genus & 43 & 17 & 0.104 \\
\hline Dytiscidae & Coleoptera & Family & 64 & 17 & 0.105 \\
\hline Microcylloepus & Coleoptera & Genus & 9 & 17 & 0.105 \\
\hline Lymnaeidae & Non-Insect & Family & 11 & 18 & 0.106 \\
\hline Isoperla & Plecoptera & Genus & 65 & 19 & 0.11 \\
\hline Planorbidae & Non-Insect & Family & 17 & 19 & 0.11 \\
\hline Sialis & Insect-Other & Genus & 25 & 19 & 0.11 \\
\hline Cheumatopsyche & Trichoptera & Genus & 26 & 20 & 0.112 \\
\hline Dolichopodidae & Diptera & Family & 10 & 20 & 0.112 \\
\hline Haliplidae & Coleoptera & Family & 9 & 20 & 0.113 \\
\hline Asellidae & Non-Insect & Family & 12 & 21 & 0.114 \\
\hline Sphaeriidae & Non-Insect & Family & 176 & 21 & 0.114 \\
\hline Centroptilum & Ephemeroptera & Genus & 6 & 21 & 0.115 \\
\hline Dolophilodes & Trichoptera & Genus & 4 & 21 & 0.115 \\
\hline Libellulidae & Insect-Other & Family & 2 & 21 & 0.115 \\
\hline Muscidae & Diptera & Family & 10 & 21 & 0.116 \\
\hline Pedicia & Diptera & Genus & 10 & 21 & 0.116 \\
\hline Physa & Non-Insect & Genus & 28 & 21 & 0.116 \\
\hline Corydalidae & Insect-Other & Family & 7 & 22 & 0.118 \\
\hline Farula & Trichoptera & Genus & 2 & 22 & 0.118 \\
\hline Molophilus & Diptera & Genus & 2 & 24 & 0.122 \\
\hline Onocosmoecus & Trichoptera & Genus & 19 & 25 & 0.124 \\
\hline Tipula & Diptera & Genus & 34 & 25 & 0.124 \\
\hline Coenagrionidae & Insect-Other & Family & 25 & 25 & 0.125 \\
\hline Dubiraphia & Coleoptera & Genus & 7 & 25 & 0.126 \\
\hline Corixidae & Insect-Other & Family & 6 & 26 & 0.127 \\
\hline Protoptila & Trichoptera & Genus & 2 & 26 & 0.128 \\
\hline Corbicula & Non-Insect & Genus & 2 & 27 & 0.129 \\
\hline Hyalella & Non-Insect & Genus & 15 & 27 & 0.13 \\
\hline Gammarus & Non-Insect & Genus & 12 & 28 & 0.131 \\
\hline Helichus & Coleoptera & Family & 8 & 28 & 0.131 \\
\hline Ptychopteridae & Diptera & Family & 12 & 31 & 0.139 \\
\hline Pseudostenophylax & Trichoptera & Genus & 3 & 34 & 0.144 \\
\hline Curculionidae & Coleoptera & Family & 1 & 41 & 0.159 \\
\hline Prodiamesinae & Diptera & Sub-Family & 8 & 41 & 0.16 \\
\hline Callibaetis & Ephemeroptera & Genus & 2 & 63 & 0.199 \\
\hline Talitridae & Non-Insect & Family & 1 & 72 & 0.217 \\
\hline
\end{tabular}

\section{References}

Angradi, T.R., 1999. Fine sediment and macroinvertebrate assemblages in Appalachian streams: a field experiment with biomonitoring applications. J. North Am. Benthol. Soc. 49-66.

Bailey, R.C., Kennedy, M.G., Dervish, M.Z., Taylor, R.M., 1998. Biological assessment of freshwater ecosystems using a reference condition approach: comparing predicted and actual benthic invertebrates communities in Yukon streams. Freshw. Biol. 39, 765-774.

Bailey, R.C., Norris, R.H., Reynoldson, T.B., 2004. Bioassessment of Freshwater Ecosystems: Using the Reference Condition Approach. Springer, New York, New York, USA, pp. 170 .

Birks, H.J.B., Line, J.M., Juggins, S., Stevenson, A.C., ter Braak, C.J.F., 1990. Diatoms and $\mathrm{pH}$ reconstruction. Philos. Trans. R. Soc. Lond. B Ser. Biol. Sci. 327, $263-278$.

Birks, H.J.B., 1998. Numerical tools in quantitative palaeolimnology-progress, potentialities and problems. J. Palaeolimnol. 20, 307-332.
Black, R.W., Munn, M.D., Plotnikoff, R.W., 2004. Using macroinvertebrates to identify biota-land cover optima at multiple scales in the Pacific Northwest, USA. J. North Am. Benthol. Soc. 23 (2), 340-362.

Bunte, K., Abt, S.R., 2001. Sampling Surface and Subsurface Particle-size Distributions in Wadeable Gravel- and Cobble-bed Streams for Analyses in Sediment Transport, Hydraulics, and Streambed Monitoring. Gen. Tech. Rep. RMRS-GTR74. U.S. Department of Agriculture, Forest Service, Rocky Mountain Research Station, Fort Collins, CO, 428 p.

Cairns Jr., J., Pratt, J.R., 1993. A history of biological monitoring using benthic macroinvertebrates. In: Rosenburg, D.M., Resh, V.H. (Eds.), Freshwater Biomonitoring and Benthic Macroinvertebrates. Chapman and Hall, New York, USA, pp. $10-27$.

Carlisle, D.M., Meador, M.R., Moulton, S.R., Ruhl, P.M., 2007. Estimation and application of indicator values for common macroinvertebrate genera and families of the United States. Ecol. Indic. 7 (1), 22-33.

Caton, L.W., 1991. Improved subsampling methods for the EPA "Rapid Bioassessment" benthic protocols. Bull. North Am. Benthol. Soc. 8 (3), 317-319. 
Chessman, B.C., McEvoy, P.K., 1998. Towards diagnostic biotic indices for river macroinvertebrates. Hydrobiologia 364, 169-182.

Chutter, F.M., 1969. The effects of silt and sand on the invertebrate fauna or streams and rivers. Hydrobiologia 34, 57-76.

Cover, M.R., May, C.L., Dietrich, W.E., Resh, V.H., 2008. Quantitative linkages among sediment supply, streambed fine sediment, and benthic macroinvertebrates in northern California streams. J. North Am. Benthol. Soc. 27 (1), 135-149.

Cuffney, T.F., Bilger, M.D., Haigler, A.M., 2007. Ambiguous taxa: effects on the characterization and interpretation of invertebrate assemblages. J. North Am. Benthol. Soc. 26 (2), 286-307

Cumming, B.F., Wilson, S.E., Hall, R.I., Smol, J.P., 1995. Diatoms from British Columbia (Canada) lakes and their relationship to salinity, nutrients and other limnological variables. In: Lange-Bertalot, H. (Ed.), Biblioteca diatomologica, Band 31. J. Cramer, Berlin, pp. 1-207.

Drake, D., 2004. Selecting Reference Condition Sites: An Approach for Biological Criteria and Watershed Assessment. Oregon Department of Environmental Quality, Report \#: WSA04-0021. http://www.deq.state.or.us/lab/techrpts/ bioreports.htm.

Engel, S.R., Voshell, J.R., 2002. Volunteer biological monitoring: can it accurately assess the ecological conditions of streams? Am. Entomol. 48 (3), 164-177.

Extence, C.A., Chadd, R.P., England, J., Dunbar, M.J., Wood, P.J., Taylor, E.D., 2013. The assessment of fine sediment accumulation in rivers using macro-invertebrate community response. River Res. Appl. 29, 17-55.

Faustini, J.M., Kaufmann, P.R., 2007. Adequacy of visually classified particle count statistics from regional stream habitat surveys1. J. Am. Water Resour. Assoc. 43 (5), 1293-1315.

Fore, L.S., Paulsen, K., O'laughlin, K., 2001. Assessing the performance of volunteers in monitoring streams. Freshw. Biol. 46, 109-123.

Fossati, O., Wasson, J.-G., Hery, C., Salinas, G., Marin, R., 2001. Impact of sediment releases on water chemistry and macroinvertebrate communities in clear water Andean streams (Bolivia). Arch. Hydrobiol. 151 (1), 33-50.

Glendell, M., Extence, C., Chadd, R., Brazier, R.E., 2014. Testing the pressure-specific invertebrate index (PSI) as a tool for determining ecologically relevant targets for reducing sedimentation in streams. Freshw. Biol. 59 (2), 353-367.

Hall, R.I., Smol, J.P., 1992. A weighted-averaging regression and calibration model for inferring total phosphorus concentration from diatoms in British Columbia (Canada) Lakes. Freshw. Biol. 27, 417-434.

Hamalainen, H., Huttunen, P., 1996. Inferring the minimum $\mathrm{pH}$ of streams from macroinvertebrates using weighed averaging regression and calibration. Freshw. Biol. 36, 697-709.

Hargett, E.G., ZumBerge, J.R., Hawkins, C.P., Olson, J.R., 2007. Development of a RIVPACS-type predictive model for bioassessment of wadeable streams in Wyoming. Ecol. Indic. 7 (4), 807-826.

Hawkins, C.P., Norris, R.H., Hogue, J.N., Feminella, J.W., 2000. Development and evaluation of predictive models for measuring the biological integrity of streams. Ecol. Appl. 10, 1456-1477.

Hawkes, H.A., 1979. Invertebrates as indicators of river water quality. In: James, A., Evison, L. (Eds.), Biological Indicators of Water Quality. John Wiley Publishers, Chichester, England.

Hayslip, G., 2007. Methods for the Collection and Analysis of Benthic Macroinvertebrate Assemblages in Wadeable Streams of the Pacific Northwest. Pacific Northwest Aquatic Monitoring Partnership, Cook, Washington.

Hering, D., Moog, O., Sandin, L., Verdonschot, P.F., 2004. Overview and application of the AQEM assessment system. Hydrobiologia 516 (1-3), 1-20.

Herlihy, A.T., Larsen, D.P., Paulsen, S.G., Urquhart, N.S., Rosenbaum, B.J., 2000. Designing a spatially balanced, randomized site selection process for regional stream surveys: the EMAP Mid-Atlantic pilot study. Environ. Monit. Assess. 63, 95-113.

Hodkinson, I.D., Jackson, J.K., 2005. Terrestrial and aquatic invertebrates as bioindicators for environmental monitoring, with particular reference to mountain ecosystems. Environ. Manage. 35 (5), 649-666.

Hornig, C.E., Brusven, M.A., 1986. Effects of suspended sediment on leaf processing by Hesperophylax occidentalis (Trichoptera: Limnephilidae) and Pteronarcys californica (Plecoptera: Pteronarcidae). Great Basin Nat., 33-38.

Hubler, S.L., 2007. Wadeable Stream Conditions in Oregon. Oregon Department of Environmental Quality, Report \#: DEQ07-LAB-0081-TR. http://www.deq.state. or.us/lab/techrpts/bioreports.htm.

Jensen, D.W., Steel, E.A., Fullerton, A.H., Pess, G.R., 2009. Impact of fine sediment on egg-to-fry survival of Pacific salmon: a meta-analysis of published studies. Rev. Fish. Sci. 17 (3), 348-359.

Jones, J.I., Murphy, J.F., Collins, A.L., Sear, D.A., Naden, P.S., Armitage, P.D., 2012. The impact of fine sediment on macro-invertebrates. River Res. Appl. 28, 1055-1071.

Jones, I., Growns, I., Arnold, A., McCall, S., Bowes, M., 2015. The effects of increased flow and fine sediment on hyporheic invertebrates and nutrients in stream mesocosms. Freshw. Biol. 60 (4), 813-826.

Juggins, S., 2007. C2 Version 1.5 User Guide. Software for Ecological and Palaeoecological Data Analysis and Visualisation. Newcastle University, Newcastle upon Tyne, UK, 73 pp.

Juggins, S., Simpson, G.L., Telford, R.J., 2015. Taxon selection using statistical learning techniques to improve transfer function prediction. Holocene 25 (1), 130-136.

Kaller, M.D., Hartman, K.J., 2004. Evidence of a threshold level of fine sediment accumulation for altering benthic macroinvertebrate communities. Hydrobiologia 518 (1-3), 95-104.

Karr, J.R., 1981. Assessment of biotic integrity using fish communities. Fisheries 6, 21-27.

Karr, J.R., 1991. Biological integrity: a long neglected aspect of water resources management. Ecol. Appl. 1, 66-84.
Karr, J.R., Yoder, C.O., 2004. Biological assessment and criteria improve total maximum daily load decision making. J. Environ. Eng. 130 (6), 594-604.

Kaufmann, P.R., Levine, P., Robison, E.G., Seeliger, C., Peck, D.G., 1999. Quantifying Physical Habitats in Wadeable Streams. EPA/620/R-99/003. U. S. Environmental Protection Agency, Washington, DC.

Kefford, B.J., Zalizniak, L., Dunlop, J.E., Nugegoda, D., Choy, S.C., 2010. How are macroinvertebrates of slow flowing lotic systems directly affected by suspended and deposited sediments? Environ. Pollut. 158 (2), 543-550.

Kent, T.R., Stelzer, R.S., 2008. Effects of deposited fine sediment on life history traits of Physa integra snails. Hydrobiologia 596 (1), 329-340.

Larsen, J., Birks, H.J.B., Raddum, G.G., Fjellheim, A., 1996. Quantitative relationships of invertebrates to $\mathrm{pH}$ in Norwegian river systems. Hydrobiologia 328, 57-74.

Lemly, A.D., 1982. Modification of benthic insect communities in polluted streams: combined effects of sedimentation and nutrient enrichment. Hydrobiologia 87, 229-245.

Mathers, K.L., Millett, J., Robertson, A.L., Stubbington, R., Wood, P.J., 2014. Faunal response to benthic and hyporheic sedimentation varies with direction of vertical hydrological exchange. Freshw. Biol. 59 (11), 2278-2289.

McClelland, W.T., Brusven, M.A., 1980. Effects of sedimentation on the behavior and distribution of riffle insects in a laboratory stream. Aquat. Insects 2, 161-169.

Mulvey, M.P., Leferink, R.K., Borisenko, A.N., 2009. Willamette Basin Rivers and Streams Assessment. Oregon Department of Environmental Quality, Report \#: DEQ 09-LAB-016. http://www.deq.state.or.us/lab/wqm/assessment.htm.

Murphy, J.F., et al., 2015. Development of a biotic index using stream macroinvertebrates to assess stress from deposited fine sediment. Freshw. Biol. 60 (10), 2019-2036.

NMFS (National Marine Fisheries Service), 2014. Final Recovery Plan for the Southern Oregon/Northern California Coast Evolutionarily Significant Unit of Coho Salmon (Oncorhynchus kisutch). National Marine Fisheries Service, Arcata, CA.

Ode, P.R., Hawkins, C.P., Mazor, R.D., 2008. Comparability of biological assessments derived from predictive models and multimetric indices of increasing geographic scope. J. North Am. Benthol. Soc. 27 (4), 967-985.

Olsen, A.R., Peck, D.V., 2008. Survey design and extent estimates for the Wadeable Streams Assessment. J. North Am. Benthol. Soc. 27 (4), 822-836.

Omernik, K.M., 1987. Ecoregions of the conterminous United States. Ann. Assoc. Am. Geogr. 77, 118-125

ODEQ (Oregon Department of Environmental Quality), 2005. Oregon Coast Coho Assessment Water Quality Report, Report \# 08-LAB-006. http://www.deq.state. or.us/lab/techrpts/bioreports.htm.

Pan, Y., Stevenson, R.J., Hill, B.H., Herlihy, A.T., Collins, G.B., 1996. Using diatoms as indicators of ecological conditions in lotic systems: a regional assessment. J. North Am. Benthol. Soc. 15, 481-495.

Paulsen, S.G., Mayio, A., Peck, D.V., Stoddard, J.L., Tarquinio, E., Holdsworth, S.M. Van Sickle, J., Yuan, L.L., Hawkins, C.P., Herlihy, A.T., Kaufmann, P.R., Barbour, M.T., Larsen, D.P., Olsen, A.R., 2008. Condition of stream ecosystems in the US: an overview of the first national assessment. J. North Am. Benthol. Soc. 27 (4), 812-821.

Peck, D.V., Herlihy, A.T., Hill, B.H., Hughes, R.M., Kaufmann, P.R., Klemm, D.J. Lazorchak, J.M., McCormick, F.H., Peterson, S.A., Ringold, P.L., Magee, T., Cappaert, M.R., 2006. Environmental Monitoring and Assessment Program-Surface Waters Western Pilot Study: Field Operations Manual for Wadeable Streams. EPA/620/R-06/003. Office of Research and Development, US Environmental Protection Agency, Washington, DC.

PNAMP (Pacific Northwest Aquatic Monitoring Partnership), 2015. Northwest Standard Taxonomic Effort, http://www.pnamp.org/project/4210.

Ponader, K.C., Charles, D.F., Belton, T.J., 2007. Diatom-based TP and TN inference models and indices for monitoring nutrient enrichment of New Jersey streams. Ecol. Indic. 7 (1), 79-93.

PRISM, 2004. PRISM Climate Group. Oregon State University, http://prism. oregonstate.edu (created 4.2.04).

Reavie, E.D., Hall, R.I., Smol, J.P., 1995. An expanded weighted-averaging model for inferring past total phosphorous concentrations from diatom assemblages in eutrophic British Columbia (Canada) lakes. J. Palaeolimnol. 14, 49-67.

Rehn, A.C., Ode, P.R., Hawkins, C.P., 2007. Comparisons of targeted-riffle and reachwide benthic macroinvertebrate samples: implications for data sharing in stream-condition assessments. J. North Am. Benthol. Soc. 26 (2), 332-348.

Relyea, C.D., Minshall, G.W., Danehy, R.J., 2012. Development and validation of an aquatic fine sediment biotic index. Environ. Manage. 49 (1), 242-252.

Reynoldson, T.B., Wright, J.F., 2000. The reference condition: problems and solutions. In: Wright, J.F., Sutcliffe, D.W., Furse, M.T. (Eds.), Assessing the Biological Quality of Freshwaters. RIVPACS and Other Techniques. Freshwater Biological Association, Ambleside, UK, pp. 303-313.

Roper, B.B., Buffington, J.M., Bennett, S., Lanigan, S.H., Archer, E., Faustini, J., Hillman, T.W., Hubler, S., Jones, K., Jordan, C., Kaufmann, P.R., Merritt, G., Moyer, C., 2010 A comparison of the performance and compatibility of protocols used by seven monitoring groups to measure stream habitat in the Pacific Northwest. North Am. J. Fish. Manage. 30, 565-587.

Rosenburg, D.M., Resh, V.H., 1993. Introduction to freshwater biomonitoring and benthic macroinvertebrates. In: Rosenburg, D.M., Resh, V.H. (Eds.), Freshwater Biomonitoring and Benthic Macroinvertebrates. Routledge, Chapman and Hall, New York, pp. 1-9.

Runde, J.M., Hellenthal, R.A., 2000. Effects of suspended particles on net-tending behaviors for Hydropsyche sparna (Trichoptera: Hydropsychidae) and related species. Ann. Entomol. Soc. Am 93 (3), 678-683.

Ryan, P.A., 1991. Environmental effects of sediment on New Zealand streams: a review. N. Z. J. Mar. Freshw. Res. 25 (2), 207-221. 
Smith, M.J., Kay, W.R., Edward, D.H.D., Papas, P.J., Richardson, K.J., Simpson, J.C., Pinder, A.M., Cale, D.J., Horowitz, P.H.J., Davis, J.A., Yung, F.H., Norris, R.H., Halse, S.A., 1999. AusRivAS: using macroinvertebrates to assess ecological condition of rivers in Western Australia. Freshw. Biol. 41 (2), 269-282.

Stoddard, J.L., Peck, D.V., Olsen, A.R., Larsen, D.P., Van Sickle, J., Hawkins, C.P., Hughes, R.M., Whittier, T.R., Lomnicky, G., Herlihy, A.T., Kaufmann, P.R., Peterson, S.A., Ringold, P.L., Paulsen, S.G., Blair, R., 2005. Environmental Monitoring and Assessment Program (EMAP) Western Streams and Rivers Statistical Summary. EPA 620/R-05/006. United States Environmental Protection Agency, Office of Research and Development.

Stoddard, J.L., Larsen, D.P., Hawkins, C.P., Johnson, R.K., Norris, R.H., 2006. Setting expectations for the ecological condition of streams: the concept of reference condition. Ecol. Appl. 16 (4), 1267-1276.

Strand, R.M., Merritt, R.W., 1997. Effects of episodic sedimentation on the netspinning caddisflies Hydropsyche betteni and Ceratopsyche sparna (Trichoptera: Hydropsychidae). Environ. Pollut. 98 (1), 129-134.

Suttle, K.B., Power, M.E., Levine, J.M., McNeely, C., 2004. How fine sediment in riverbeds impairs growth and survival of juvenile salmonids. Ecol. Appl. 14 (4), 969-974.

Telford, R.J., Birks, H.J.B., 2011. Effect of uneven sampling along an environmental gradient on transfer-function performance. J. Paleolimnol. 46 (1), 99-106.

Telford, R.J., Andersson, C., Birks, H.J.B., Juggins, S., 2004. Biases in the estimation of transfer function prediction errors. Paleoceanography 19 (4).

ter Braak, C.J., Barendregt, L.G., 1986. Weighted averaging of species indicator values: its efficiency in environmental calibration. Math. Biosci. 78 (1), 57-72.

ter Braak, C.J.F., Looman, C.W.N., 1986. Weighted averaging, logistic regression and the Gaussian response model. Vegetatio 65, 3-11.

Ter Braak, C.J.F., van Dam, H., 1989. Inferring pH from diatoms-a comparison of old and new calibration methods. Hydrobiologia 178, 209-223. ter Braak, C.J.F., Juggins, S., 1993. Weighted averaging partial least squares regression (WA-PLS): an improved method for reconstructing environmental variables from species assemblages. Hydrobiologia 269, 485-502.

Turley, M.D., Bilotta, G.S., Extence, C.A., Brazier, R.E., 2014. Evaluation of a fine sediment biomonitoring tool across a wide range of temperate rivers and streams. Freshw. Biol. 59 (11), 2268-2277.

Von Bertrab, M.G., Krein, A., Stendera, S., Thielen, F., Hering, D., 2013. Is fine sediment deposition a main driver for the composition of benthic macroinvertebrate assemblages? Ecol. Indic. 24, 589-598.

Whitney, L., 2007. Upper Grande Ronde Basin Section 319 National Monitoring Program Project: Summary Report. Oregon Department of Environmental Quality, Report \# DEQ07-LAB-0058-TR. http://www.deq.state.or.us/lab/techrpts/ bioreports.htm.

Wright, J.F., Furse, M.T., Armitage, P.D., 1993. RIVPACS: a technique for evaluating the biological water quality of Rivers in the UK. Eur. Water Pollut. Control 3, 15-25.

Wood, P.J., Armitage, P.D., 1997. Biological effects of fine sediment in the lotic environment. Environ. Manage. 21 (2), 203-217.

Wood, P.J., Toone, J., Greenwood, M.T., Armitage, P.D., 2005. The response of four lotic macroinvertebrate taxa to burial by sediments. Arch. Hydrobiol. 163 (2), $145-162$.

Yagow, G., Wilson, B., Srivastava, P., Obropta, C.C., 2006. Use of biological indicators in TMDL assessment and implementation. Trans. Am. Soc. Agric. Biol. Eng. 49 (4), 1023-1032.

Yuan, L.L., 2004. Assigning macroinvertebrate tolerance classifications using generalised additive models. Freshw. Biol. 49 (5), 662-677.

Yuan, L.L., 2005. Sources of bias in weighted average inferences of environmental conditions. J. Paleolimnol. 34 (2), 245-255.

Yuan, L.L., 2007. Using biological assemblage composition to infer the values of covarying environmental factors. Freshw. Biol. 52 (6), 1159-1175. 